\title{
Chapter 29
}

\section{Anatomical Distribution of Nucleoside System in the Human Brain and Implications for Therapy}

\author{
Zsolt Kovács and Arpád Dobolyi
}

\begin{abstract}
Nucleosides have a wide range of physiological and pathophysiological roles in the human brain as modulators of a variety of neural functions. For example, adenosine, inosine, guanosine, and uridine participate in the mechanisms underlying memory, cognition, sleep, pain, depression, schizophrenia, epilepsy, Alzheimer's disease, Huntington's disease, and Parkinson's disease. Consequently, increasing attention is now being given to the specific role of nucleosides in physiological and pathological processes in the human brain. Different elements of nucleoside system, including nucleoside concentrations, metabolic enzyme activity, and expression of nucleoside transporters and receptors, may be changed under normal and pathological conditions. The alterations suggest that interlinked elements of the nucleoside system are functioning in a tightly concerted manner.

Nucleoside levels, activity of nucleoside metabolic enzymes, and expression of nucleoside transporters and receptors are unevenly distributed in the brain, suggesting that nucleosides have different roles in functionally distinct human brain areas. The aim of this chapter is to summarize our present knowledge of the anatomical distribution of nucleoside system in the human brain, placing emphasis on potential therapeutic pharmacological strategies.
\end{abstract}

Keywords Nucleosides • Anatomical distribution of nucleoside system • Human brain diseases and therapy

\footnotetext{
Z. Kovács $(\bowtie)$

Department of Zoology, University of West Hungary, Savaria Campus, Károlyi Gáspár tér 4, Szombathely 9700, Hungary

e-mail: zskovacs@ttk.nyme.hu
A. Dobolyi
Neuromorphological and Neuroendocrine Research Laboratory, Department of Anatomy, Histology and Embryology, Semmelweis University and the Hungarian Academy of Sciences, Budapest, Hungary 


\section{Abbreviations}

5'NT

$\mathrm{A}_{1}$ receptor/ $\mathrm{A}_{2 \mathrm{~A}}$ receptor/

$\mathrm{A}_{2 \mathrm{~B}}$ receptor $/ \mathrm{A}_{3}$ receptor

AC

ADA

Ade

ADK

Ado

AMP

CDP-choline

$\mathrm{cN}$

CNS

CNT transporters

CNT1/CNT2/CNT3 transporters

Cyd

EC

ENT transporters

ENT1/ENT2/ENT3/ENT4 transporters

"es" nucleoside transporters

GABA
GDA
GMP
Gn
Guo
Hyp
IMP
Ino
NBTI
PLC
PNP
Urd
Xn

5'-Nucleotidases

$A_{1} R / A_{2 A} R / A_{2 B} R / A_{3} R$ subtype of adenosine receptors

Adenylate cyclase

Adenosine deaminase

Adenine

Adenosine kinase

Adenosine

Adenosine monophosphate

Cytidine diphosphocholine

Cytoplasmic 5'-nucleotidases

Central nervous system

Concentrative nucleoside transporters

CNT1/CNT2/CNT3 subtype of concentrative nucleoside transporters

Cytidine

Extracellular

Equilibrative nucleoside transporters

ENT1/ENT2/ENT3/ENT4 subtype of equilibrative nucleoside transporters Equilibrative, NBTI sensitive type of ENT transporters

$\gamma$-Aminobutyric acid

Guanine deaminase

Guanosine monophosphate

Guanine

Guanosine

Hypoxanthine

Inosine monophosphate

Inosine

$S$-(4-nitrobenzyl)-6-thioinosine

Phospholipase C

Purine nucleoside phosphorylase

Uridine

Xanthine 


\subsection{Introduction}

Nucleosides such as adenosine (Ado), guanosine (Guo), inosine (Ino), and uridine (Urd) have a role in the regulation of neuronal and glial functions in the brain (Burnstock et al. 2011; Dobolyi et al. 2011; Fields and Burnstock 2006; Haskó et al. 2004; Schmidt et al. 2007). In addition, nucleosides participate in physiological and pathophysiological processes in the brain, such as the regulation of sleep and memory, epilepsy, Parkinson's disease, and Alzheimer's disease (Dobolyi et al. 2011; Huang et al. 2011; Lopes et al. 2011; Sperlágh and Vizi 2011). Increasingly, nucleoside derivatives and uptake or metabolic inhibitors are being used in clinical or preclinical drug development for the treatment of different diseases, ranging from viral infections to neurodegenerative disorders (Boison 2011; Lopes et al. 2011; Parkinson et al. 2011).

Regional differences occur in the nucleoside system of the human central nervous system (CNS). Nucleoside levels, metabolic enzymes, transporters, and receptors are unevenly distributed in the human brain (Baldwin et al. 2005; Barnes et al. 2006; Dawson 1971; Fredholm et al. 2001; Jennings et al. 2001; Kovács et al. 1998, 2010a; Nagata et al. 1984; Norstrand et al. 1984; Norstrand and Glantz 1980; Pennycooke et al. 2001; Phillips and Newsholme 1979; Ritzel et al. 2001). In addition, nucleoside concentrations are dependent on age and gender (Kovács et al. 2010b). These results suggest region-, age-, and gender-dependent functions of nucleosides in the human brain. Correlations have been observed between the (1) $S$-(4-nitrobenzyl)-6-thioinosine (NBTI) binding site and the density of adenosine deaminase (ADA) immunoreactive neurons (Geiger and Nagy 1986), (2) regional differences in nucleoside levels and the nucleoside metabolic enzyme activities and distribution of adenosine receptors (Kovács et al. 2010a), (3) ENT1 subtype of equilibrative nucleoside transporters (ENT1) and $A_{1}$ adenosine receptor subtype $\left(A_{1} R\right)$ density (Jennings et al. 2001), and (4) $A_{1} R$ density and 5'-nucleotidase (5'NTs) levels (Fastbom et al. 1987). Interactions have also been observed between $\mathrm{ADA}$ and $\mathrm{A}_{1} \mathrm{Rs}$, resulting in the facilitation of agonist binding to $A_{1}$ Rs and the enhancement of receptor functionality in the human caudate nucleus (Gracia et al. 2008). These results strengthen the hypothesis that the so-called "purinome" groups nucleoside and nucleotide receptors, transporters, metabolic enzymes and ligands together to organize purinergic signaling (Kovács and Dobolyi 2011; Volonté and D'Ambrosi 2009). Complex anatomical, biochemical, and pharmacological analyses of the purinome are necessary to understand the functions of nucleoside system and to develop novel and safe drugs to treat various CNS diseases.

The aim of this chapter is to summarize the anatomical distribution of the nucleoside system in the human brain and to examine their potential for the development of pharmacological therapies. We focus on four nucleosides, Ado, Ino, Guo, and Urd. The available knowledge regarding the physiological and/or pathophysiological role of other nucleosides in the human brain is too limited for comprehensive evaluation. We briefly summarize some relevant features of the brain nucleoside system. Then we describe the anatomical distribution of nucleoside levels, metabolic enzymes, transporters, and receptors. Finally, we discuss their potential as targets of pharmacological therapeutics. 


\subsection{Nucleosides in the Human Brain: Metabolism, Transporters, and Receptors}

\subsubsection{Metabolism}

Ribonucleic acids (RNA) and deoxyribonucleic acids (DNA) are synthesized from nucleotides that are composed of nucleosides and phosphate moieties. Nucleosides contain purine or pyrimidine bases connected to a pentose moiety. The major purine ribonucleosides are Ado, Guo, Ino, while the major pyrimidine ribonucleosides are cytidine (Cyd), Urd, and thymidine (Thd) (Linden and Rosin 2006). Nucleosides are synthesized de novo in the liver and can be partly obtained from food. They are transported into the brain and metabolized to their corresponding nucleotides. De novo synthesis of nucleosides in the adult brain is limited. Therefore, a salvage mechanism in the brain preserves the purine and pyrimidine nucleosides and bases. The main precursors of nucleotides in the brain are Ado, adenine (Ade), hypoxanthine (Hyp), guanine (Gn), Urd, and Cyd. To maintain the synthesis of ribo- and deoxyribonucleotides, hypoxanthine phosphoribosyltransferase (HGPRT; hypoxanthine-guanine phosphoribosyltransferase) catalyzes the conversion of Hyp-inosine monophosphate (IMP) and Gn-guanosine monophosphate (GMP; Fig. 29.1). Adenosine kinase (ADK) converts Ado to adenosine monophosphate (AMP), but Ado can also be metabolized to IMP in salvage reactions. Ade is metabolized to AMP by the adenine phosphoribosyltransferase (APRT) salvage enzyme. Cytidine deaminase (CDA) and uridine-cytidine kinase (UCK) salvage Cyd and Urd (Ipata et al. 2011).

The degradation pathway of adenine nucleotides in the brain can convert AMP to IMP-Ino-Hyp or Ado-Ino-Hyp (Fig. 29.1). These metabolic steps are catalyzed by cytoplasmic 5'-nucleotidases (cN, 5'NT), AMP deaminase (AMPDA), ADA, and purine nucleoside phosphorylase (PNP). $S$-adenosylhomocysteine (SAH) can be converted to Ado by adenosylhomocysteinase (SAHH, $S$-adenosylhomocysteine hydrolase). The main route of guanine-ribonucleotide catabolism is the GMPGuo-Gn-Xanthine $(\mathrm{Xn})$ pathway catalyzed by $\mathrm{cN}$, PNP, and guanine deaminase

Fig. 29.1 (continued) deaminase; I: Nucleoside transporters; II: ATP channels and transporters; III: $\mathrm{K}^{+}$channels; IV: $\mathrm{Ca}^{2+}$-channels; $\mathrm{A}_{1}, \mathrm{~A}_{2 \mathrm{~A}}, \mathrm{~A}_{2 \mathrm{~B}}$ and $\mathrm{A}_{3}, \mathrm{~A}_{4}$ Adenosine receptors types; $A C$ Adenylate cyclase; ADAi Adenosine deaminase inhibitors; Ade Adenine; AdeR Adenine receptor; ADKi Adenosine kinase inhibitors; Ado Adenosine; $A D P$ Adenosine diphosphate; $A M P$ Adenosine monophosphate; ATi Adenosine transporter inhibitors; ATP Adenosine triphosphate; $c A M P$ Cyclic adenosine monophosphate; $D A G$ Diacylglycerol; $\mathrm{G}_{\mathrm{i}}, \mathrm{G}_{0}, \mathrm{G}_{\mathrm{s}}, \mathrm{G}_{\mathrm{q}}, \mathrm{G}_{\mathrm{olf}}$ : G-proteins (f.e. $\mathrm{G}_{\mathrm{i}}$ : Inhibitory, $\mathrm{G}_{\mathrm{s}}$ : Stimulatory); GMP Guanosine monophosphate; Gn Guanine; GTP Guanosine triphosphate; Guo Guanosine; GuoR Guo receptor; Hyp Hypoxanthine; IMP Inosine monophosphate; Ino Inosine; $I P_{3}$ Inositol 1,4,5-triphosphate; $M A P K$ Mitogen-activated protein kinase; $M T A$ 5'-deoxy-5'-methylthioadenosine; PIP2 Phosphatidylinositol bisphosphate; $P K A$ Protein kinase A; $P K C$ Protein kinase C; $P L C$ Phospholipase C; SAH S-adenosylhomocysteine; $s N U C$ Synthetic nucleosides/nucleoside analogues; UA Uric acid; UMP Uridine monophosphate; Ura Uracil; Urd Uridine; UrdR Urd receptor; UTP Uridine triphosphate; Xn Xanthine; XOi Xanthine oxidase inhibitors 


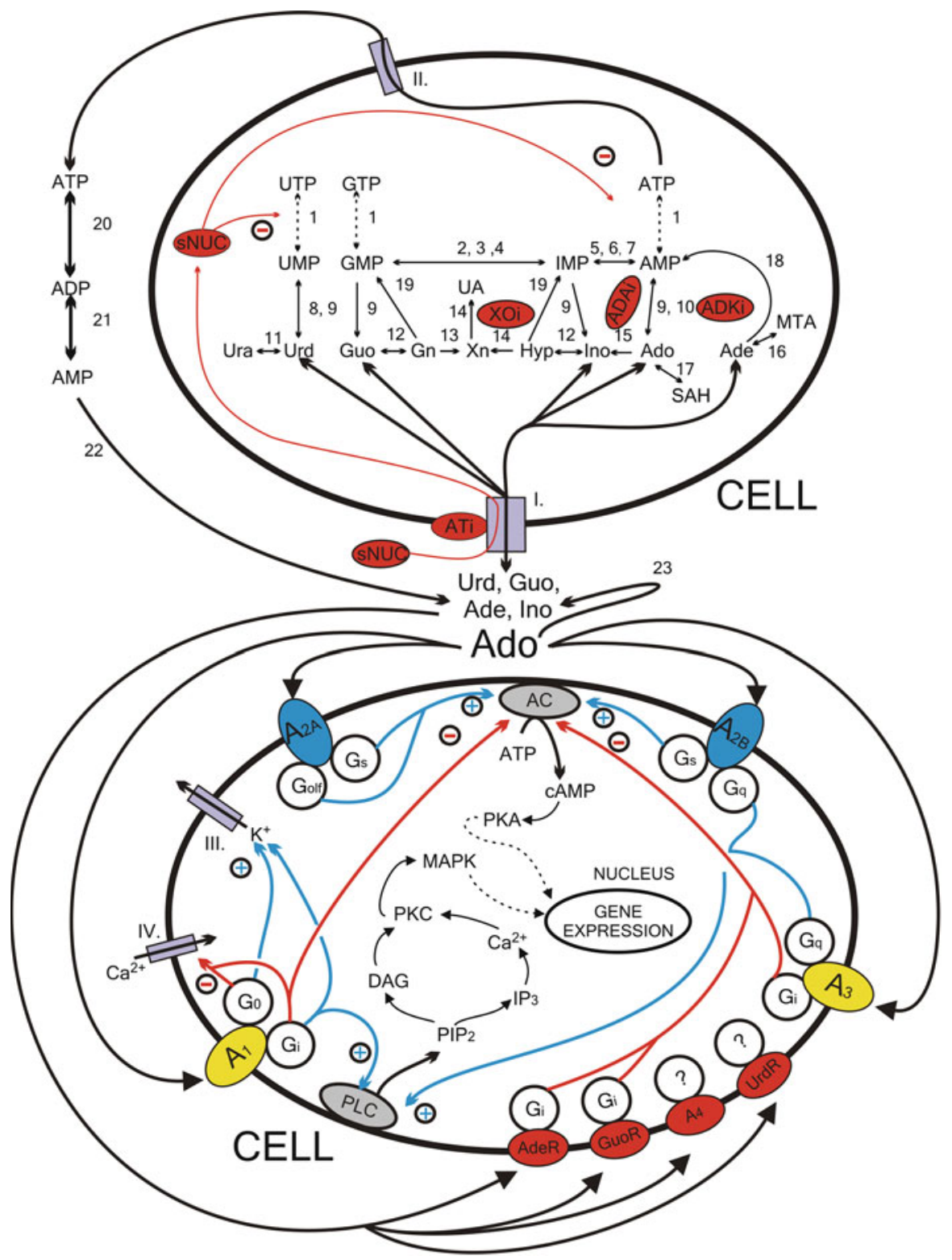

Fig. 29.1 Nucleoside production, transport and receptor signaling. Abbreviations: 1: Nucleoside mono- and diphosphate kinases and nucleoside di- and triphosphate phosphatases; 2: GMPR GMP reductase; 3: GMPS GMP synthetase; 4: IMPDH IMP dehydrogenase; 5: AMPDA AMP deaminase; 6: ASL Adenylosuccinate lyase; 7: ASS Adenylosuccinate synthetase; 8: UCK Uridinecytidine kinase; 9: 5'NT 5'-Nucleotidase; 10: $A D K$ Adenosine kinase; 11: UP Uridine phosphorylase; 12: $P N P$ Purine nucleoside phosphorylase; 13: GDA Guanine deaminase; 14: $X O$ Xanthine oxidase; 15: ADA Adenosine deaminase; 16: MTAP 5'-deoxy-5'-methylthioadenosine phosphorylase; 17: SAHH S-adenosylhomocysteine hydrolase; 18: APRT Adenine phosphoribosyltransferase; 19: HGPRT Hypoxanthine phosphoribosyltransferase (hypoxanthine-guanine phosphoribosyltransferase); 20: ecto-ATPase; 21: ecto-ADPase; 22: ecto-5'NT ecto-5'-nucleotidase (eN); 23: ecto-ADA ecto-adenosine 
(GDA; Fig. 29.1). In the final step of purine catabolism in the human brain, $\mathrm{Xn}$ is converted to uric acid (UA) by xanthine oxidase (XO). The following enzymes regulate the extracellular (EC) Ado concentration: ecto-5'-nucleotidase (eN), ectoadenosine kinase (ecto-ADK), and ecto-adenosine deaminase (ecto-ADA) (Fernández et al. 2010; Firestein et al. 1999; Ipata et al. 2011; Yegutkin 2008; Zimmermann 1996) (Fig. 29.1).

\subsubsection{Transporters}

Nucleosides are transported into and released from brain cells via nucleoside transporters (Fig. 29.1). Two types of nucleoside transporters are expressed in the human brain. The equilibrative nucleoside transporter family (ENT transporters; bidirectional facilitated diffusion) contains four ENT transporter types: ENT1-ENT4. NBTI partially inhibits ENTs at the nM concentration range ("es": equilibrative, NBTI sensitive type of ENTs, e.g., ENT1), whereas NBTI insensitive transporters are inhibited by NBTI only at the $\mu \mathrm{M}$ concentration range ("ei": equilibrative, NBTI insensitive type of ENTs, e.g., ENT2). The concentrative nucleoside transporter family (CNT transporters; unidirectional, sodium-dependent) includes six CNT transporter types (N1-N6) that are classified based on the types of nucleosides transported and sodium transport coupling (Baldwin et al. 2005; Barnes et al. 2006; Jennings et al. 2001; Parkinson et al. 2011; Pennycooke et al. 2001; Ritzel et al. 2001).

\subsubsection{Receptors}

All four known adenosine receptor subtypes $\left(A_{1}, A_{2 A}, A_{2 B}\right.$, and $A_{3}$ : also known as P1 receptors) have been identified in the human brain (Fredholm et al. 2001; Jennings et al. 2001). Adenosine receptors are G-protein-coupled receptors (GPCR; Fig. 29.1). $A_{1}$ Rs couple to "inhibitory" $G$-proteins $\left(G_{i}\right.$ and $\left.G_{0}\right)$ and inhibit adenylate cyclase (AC). $A_{2 A}$ Rs and $A_{2 B}$ Rs, however, stimulate $A C$ using "stimulatory" G-proteins $\left(G_{S}\right) \cdot A_{2 A}$ Rs may also activate $A C$ via $G_{\text {olf }}$-proteins. Similar to $A_{1} R s, A_{3}$ Rs inhibit AC by coupling with $G_{i}$-proteins. $G_{q}$ proteins can couple to $A_{2 B}$ and $A_{3}$ Rs and stimulate phospholipase $\mathrm{C}$ (PLC) activity. $\mathrm{A}_{1} \mathrm{Rs}$ can also stimulate PLC and modulate the activity of $\mathrm{K}^{+}$and $\mathrm{Ca}^{2+}$ channels. In addition, the existence of yet unidentified nucleoside receptors cannot be excluded. For example, a novel subtype of adenosine receptors $\left(\mathrm{A}_{4}\right)$ has been proposed based on electrophysiological and pharmacological criteria in the brain (Cornfield et al. 1992; Luthin and Linden 1995; Tucker and Linden 1993). It is also conceivable that Urd, Guo, and Ade have their own receptors (UrdR, GuoR, AdeR, respectively; Fig. 29.1) that are used to execute certain functions in the nervous system (Bender et al. 2002; Borrmann et al. 2009; Kimura et al. 2001; Schulte and Fredholm 2003; Traversa et al. 2002). 


\subsection{Anatomical Distribution of the Nucleoside System in the Human Brain}

\subsubsection{Distribution of Nucleoside Levels}

The concentration of nucleotide triphosphates, such as adenosine triphosphate (ATP), guanosine triphosphate (GTP), uridine triphosphate (UTP), and cytidine triphosphate (CTP), are 2-3 orders of magnitude higher $(0.2-5 \mathrm{mM})$ in the human brain than that of nucleosides are. Consequently, the degradation of nucleotide triphosphates (Fig. 29.1) may increase the levels of corresponding nucleosides over baseline concentrations. For example, a 5-60 min period of ischemia was found to cause rapid degradation of nucleotide triphosphates and increase the concentrations of nucleosides and their metabolites (Ado, Guo, Ino, Hyp, and Xn) by 2-150 times that of baseline (Berne et al. 1974; Bjerring et al. 2010; Eells and Spector 1983; Hagberg et al. 1987; Kovács et al. 2010a; Melani et al. 2003; Traut 1994).

Both animal and human experiments have determined that nucleoside concentrations are unevenly distributed in different brain areas (Kékesi et al. 2006; Kovács et al. 2010a, 2011). Kovács and colleagues (Kovács et al. 2005) developed an extrapolation method that allows realistic estimates of the in vivo nucleoside levels from postmortem frozen and microwave-treated brain bank samples. Using this method, a nucleoside map of the human brain, consisting of 61 brain and 4 spinal cord areas, was constructed. High Ado (15.9-23.9 pmol/mg), Urd (44.1-66.2 pmol/ $\mathrm{mg}$ ), Ino (107.7-161.5 pmol/mg), and Guo (17.7-26.4 pmol/mg) concentrations were observed in several regions, including the cochlear nuclei, vestibular nuclei, cerebellar cortex, supraoptic nucleus, flocculonodular lobe, spinal trigeminal nucleus, temporal and occipital cortices, caudate nucleus, nucleus basalis, medial geniculate body, amygdala, spinal central gray, and ventral horn of the spinal cord (Table 29.1). The lowest concentrations of Ado (1.4-7.9 pmol/mg), Urd (15.7-22.0 pmol/mg), Ino (29.8-53.8 pmol/mg), and Guo (4.1-8.8 pmol/mg) were measured in the entorhinal cortex, septum, habenula, zona incerta, substantia nigra, locus coeruleus, preoptic area, pulvinar, and inferior colliculus (Table 29.1). Nucleoside metabolites such as Hyp, Xn, and uracil/Ura, (Fig. 29.1) were also unevenly distributed in the human brain (Kovács et al. 2010a).

Age and gender may modulate nucleoside expression. For example, the levels of Ino and Ado in the frontal cortex increase with age. Urd, Ino, and Guo concentrations are higher in the frontal cortex and white matter of middle-aged women when compared to middle-aged men, whereas Ado levels are lower in the frontal cortex of both middle-aged and elderly women when compared to men (Kovács et al. 2010b). These results suggest that the nucleoside microenvironment in the human brain may be an important factor in the aging processes and nucleosides might play a part in the reduced vulnerability of female brains to excitotoxic insults (Kovács et al. 2010b). 
Table 29.1 Levels of nucleosides, activity of some nucleoside metabolizing enzymes, and relative density of nucleoside transporters and adenosine receptors in the human CNS

\begin{tabular}{|c|c|}
\hline \multicolumn{2}{|c|}{ Anatomical distribution of nucleoside system } \\
\hline \multicolumn{2}{|c|}{ Nucleosides in the CNS } \\
\hline Nucleosides & Nucleoside levels (pmol/mg wet weight) \\
\hline \multirow[t]{3}{*}{ Ado } & $\begin{array}{l}\text { High (15.9-23.9): cochlear nuclei, vestibular nuclei, cerebellar cortex, supraoptic } \\
\text { nucleus, flocculonodular lobe }\end{array}$ \\
\hline & $\begin{array}{l}\text { Intermediate }(8.0-15.8) \text { : spinal cord (ventral and dorsal horn })^{+}, \text {amygdala } \\
\text { temporal } \\
\text { nucleus }^{+} \text {, and prefrontal cortex }\end{array}$ \\
\hline & $\begin{array}{l}\text { Low (1.4-7.9): frontal, somatosensory, cingulate, and entorhinal cortex; hip- } \\
\text { pocampus, nuclei of diagonal band, septum, globus pallidus externa, ventral } \\
\text { lateral nucleus, habenula, pulvinar, zona incerta, preoptic area, paraventricular } \\
\text { nucleus, dorsomedial nucleus (hypothalamus), lateral hypothalamic area, } \\
\text { substantia nigra, inferior colliculus, locus coeruleus, dorsal vagal nuclei, } \\
\text { nucleus accumbens }{ }^{+} \text {, spinal central gray }{ }^{1}\end{array}$ \\
\hline \multirow[t]{3}{*}{ Ino } & High (107.7-161.5): cochlear nuclei, spinal trigeminal nucleus \\
\hline & $\begin{array}{l}\text { Intermediate (53.9-107.6): frontal, temporal, somatosensory }{ }^{+}, \text {prefrontal }^{+}, \\
\text {cingulate }{ }^{+} \text {, and occipital cortex; caudate nucleus, substantia innominata, } \\
\text { nucleus basalis, nucleus accumbens }{ }^{+}, \text {reticular formation (medulla oblongata), } \\
\text { amygdala }^{+} \text {, cerebellar nuclei, spinal cord (ventral and dorsal }{ }^{+} \text {horn), mediodor- } \\
\text { sal thalamic nucleus }{ }^{+} \text {, spinal cord (white matter) }\end{array}$ \\
\hline & $\begin{array}{l}\text { Low (29.8-53.8): entorhinal and parahippocampal cortex; hippocampus, nuclei of } \\
\text { diagonal band, habenula, pulvinar, zona incerta, paraventricular nucleus, } \\
\text { substantia nigra, inferior colliculus, locus coeruleus }{ }^{1}\end{array}$ \\
\hline \multirow[t]{3}{*}{ Gио } & $\begin{array}{l}\text { High (17.7-26.4): cochlear nuclei; temporal and occipital cortex; caudate nucleus, } \\
\text { nucleus basalis, medial geniculate body, amygdala }{ }^{+}\end{array}$ \\
\hline & $\begin{array}{l}\text { Intermediate (8.9-17.6): insular, prefrontal }{ }^{+} \text {, entorhinal } l^{+} \text {, } \text { cingulate }^{+} \text {, and } \\
\text { somatosensory cortex }{ }^{+} \text {; white matter (cerebral and cerebellar), nuclei of } \\
\text { diagonal band, substantia innominata, lateral geniculate body, hippocampus } \\
\text { nucleus accumbens } \\
\text { co cerebellar nuclei, mediodorsal thalamic nucleus }{ }^{+}, \text {spinal }^{+} \\
\text {cord (ventral and dorsal }{ }^{+} \text {horn) }\end{array}$ \\
\hline & $\begin{array}{l}\text { Low (4.1-8.8): septum, habenula, pulvinar, zona incerta, paraventricular nucleus, } \\
\text { lateral hypothalamic area, substantia nigra, superior colliculus, inferior } \\
\text { colliculus, locus coeruleus, spinal cord (white matter) }{ }^{1}\end{array}$ \\
\hline \multirow[t]{3}{*}{ Urd } & $\begin{array}{l}\text { High (44.1-66.2): cochlear nuclei, temporal and occipital cortex, cerebellar } \\
\text { cortex, amygdala }\end{array}$ \\
\hline & 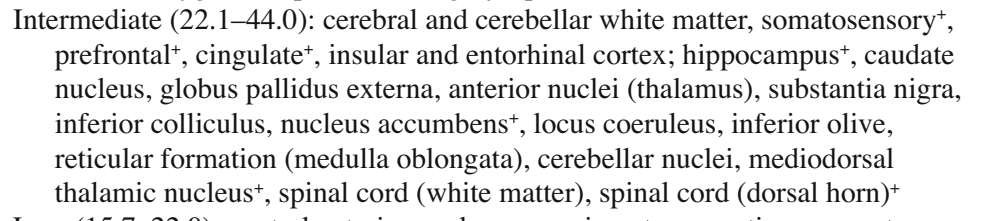 \\
\hline & $\begin{array}{l}\text { Low (15.7-22.0): ventral anterior nucleus, zona incerta, preoptic area, motor } \\
\text { facial nucleus }{ }^{1}\end{array}$ \\
\hline
\end{tabular}


Table 29.1 (continued)

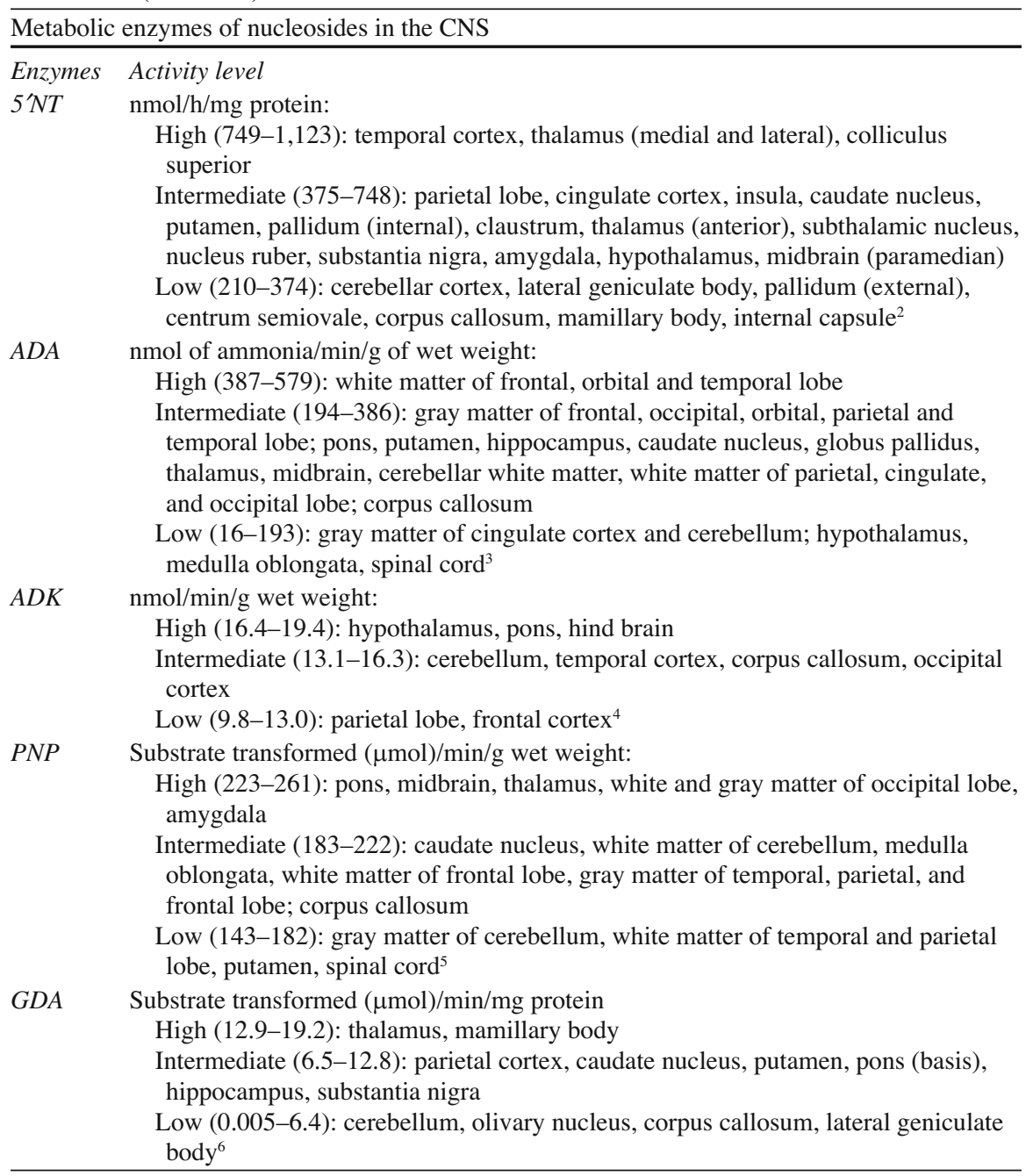

Nucleoside transporters in the CNS

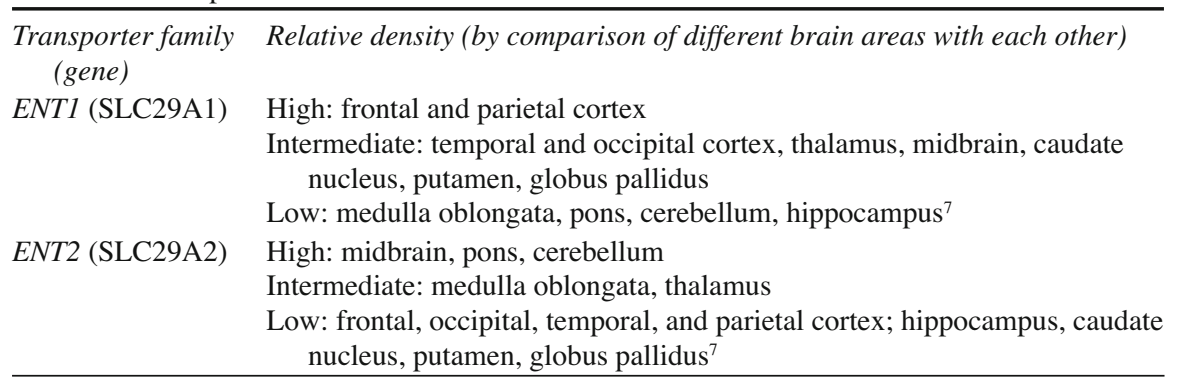


Table 29.1 (continued)

Nucleoside transporters in the CNS

ENT3 (SLC29A3) High: occipital and temporal lobe, corpus callosum, medulla oblongata, putamen

Intermediate: frontal lobe, paracentral gyrus, pons, hippocampus, nucleus accumbens, thalamus, spinal cord, cerebellum (right)

Low: parietal lobe, cerebellum (left), amygdala, caudate nucleus, substantia nigra, pituitary gland ${ }^{8}$

ENT4 (SLC29A4) High: temporal lobe, paracentral gyrus, amygdala, caudate nucleus, hippocampus, medulla oblongata, putamen

Intermediate: parietal and occipital lobe, pons, cerebellum (right), corpus callosum, thalamus, pituitary gland, spinal cord, substantia nigra, nucleus accumbens

Low: frontal lobe, cerebellum (left) ${ }^{9}$

CNT1 (N2/cit; $\quad$ Uniform distribution ${ }^{10}$

SLC28A1)

CNT2 (N1/cif;

High: cerebellum, putamen, hippocampus, medulla oblongata

SLC28A2) Intermediate/low: amygdala, cerebral cortex, frontal, occipital, and temporal lobe; substantia nigra, thalamus, spinal cord $^{10}$

CNT3 (N3/cib; High: hippocampus, medulla oblongata, pituitary gland

SLC28A3) Intermediate/low: frontal, parietal and occipital lobe; corpus callosum, cerebellum, amygdala, caudate nucleus, putamen, thalamus, temporal lobe, paracentral gyrus, pons, substantia nigra, nucleus accumbens, spinal cord ${ }^{11}$

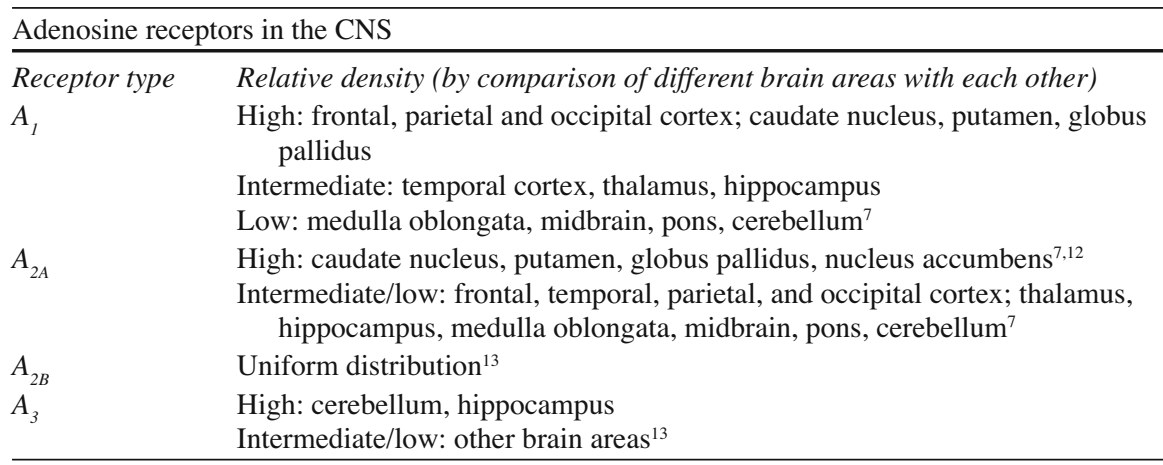

The levels of nucleosides in brain and spinal cord areas were compared to the grand average concentration values of the total brain and spinal cord areas (Kovács et al. 2010a). We also listed some brain and spinal cord areas, which are implicated in particular CNS diseases, even though their nucleoside levels did not differ from average values (these brain areas are labeled by "“”)

References: ${ }^{1}$ Kovács et al. 2010a; ${ }^{2}$ Nagata et al. 1984; ${ }^{3}$ Norstrand et al. 1984; ${ }^{4} \mathrm{Phillips}$ and Newsholme 1979; ${ }^{5}$ Norstrand and Glantz 1980; ${ }^{6}$ Dawson 1971; ${ }^{7}$ Jennings et al. 2001; ${ }^{8}$ Baldwin et al. 2005; ${ }^{9}$ Barnes et al. 2006; ${ }^{10}$ Pennycooke et al. 2001; ${ }^{11}$ Ritzel et al. $2001 ;{ }^{12}$ Svenningsson et al. 1997; ${ }^{13}$ Fredholm et al. 2001; Abbreviations: Nucleosides-Ado Adenosine, Guo Guanosine, Ino Inosine, Urd Uridine; Nucleoside metabolizing enzymes - 5'NT 5'-Nucleotidase, ADA Adenosine deaminase, $A D K$ Adenosine kinase, GDA Guanine deaminase, $P N P$ Purine nucleoside phosphorylase. For nucleoside transporter and nucleoside receptor abbreviations, see text 


\subsubsection{Distribution of Nucleoside Metabolic Enzymes}

Nucleoside metabolic enzymes form a complex network, including several alternative metabolic pathways (Ipata et al. 2011; Kovács et al. 2011) (Fig. 29.1). The distribution and activity of nucleoside metabolic enzymes are uneven in the human brain, reflecting spatial differences in the nucleoside metabolic network. The distribution of 5'NTs, ADA, ADK, PNP, and GDA (Fig. 29.1) activities in the human brain have been previously described (Dawson 1971; Nagata et al. 1984; Norstrand et al. 1984; Norstrand and Glantz 1980) (Table 29.1).

The activities of $5^{\prime}$ NT, PNP, and GDA are high in the thalamus (Table 29.1). High to intermediate activity of $5^{\prime} \mathrm{NT}$ was found in several brain regions, including the temporal cortex, colliculus superior, basal ganglia, nucleus ruber, substantia nigra, amygdala, and hypothalamus. In contrast, the cerebellar cortex, lateral geniculate body, pallidum, corpus callosum, and mamillary body showed low activity levels of this enzyme.

Interestingly, the white matter of frontal, orbital, and temporal lobes contain the highest ADA activity, while only intermediate activity has been observed in the gray matter of these brain areas (Table 29.1). An intermediate ADA activity was also found, e.g., in the basal ganglia, pons, hippocampus, and thalamus. On the contrary, low ADA activity was measured in the cerebellum, hypothalamus, medulla oblongata, and spinal cord. Others have observed the highest level of ADA activity in the hypothalamus (Phillips and Newsholme 1979).

High ADK activity has been found in the hypothalamus, pons, and hind brain. The temporal and occipital cortices and cerebellum show intermediate ADK activity, whereas the parietal lobe and frontal cortex contain low levels of this enzyme (Table 29.1). GDA activity is also high in the mamillary body. Intermediate GDA activity was measured in the parietal cortex, basal ganglia, substantia nigra, and hippocampus, with the lowest activity in the cerebellum. High PNP activity was also revealed in the pons, midbrain and amygdala whereas low enzyme activity was demonstrated, e.g., in the putamen and spinal cord.

Spatial differences in the distribution of nucleosides are correlated with nucleoside metabolic enzyme activities and the neuron-glia ratio in the human brain (Kovács et al. 2010a). Nucleoside metabolism is different in neuronal and glial cells (Ceballos et al. 1994; Zoref-Shani et al. 1995). Consequently, alterations in the glia/ neuron may cause regional differences in nucleoside levels. However, the correlation between the neuron-glia ratio and nucleoside levels in the human brain is weak (Kovács et al. 2010a). Importantly, the neuron-glia ratio is changed in some brain areas implicated in the development of major depressive and bipolar disorders, schizophrenia, Huntington's and Alzheimer's disease, and frontotemporal dementia (Bowley et al. 2002; Brauch et al. 2006; Harper et al. 2008; Öngür et al. 1998; Roos et al. 1985).

Table 29.1 shows that altered nucleoside metabolic enzyme activity may result in an uneven distribution of nucleosides and their metabolites in the human brain (Kovács et al. 2010a). For example, high or intermediate 5'NT activity and low or intermediate ADA/ADK activity can generate elevated Ado, Ino, and Guo levels 
(Fig. 29.1) in the temporal cortex and caudate nucleus (Table 29.1). High 5'NT, PNP and GDA activities may result in low Guo levels in thalamic areas, such as the habenula, pulvinar, and zona incerta (Table 29.1).

Altogether, these results suggest that the uneven distribution of nucleoside levels may be due to complex interactions between regionally different glia-neuron ratios and nucleoside metabolic enzyme activities.

\subsubsection{Distribution of Nucleoside Transporters}

The distribution of nucleoside transporters in the human brain is uneven, and the regionally different distribution of nucleoside transporters reflects the functional significance of nucleoside neuromodulation in different brain areas (Baldwin et al. 2005; Barnes et al. 2006; Jennings et al. 2001; Pennycooke et al. 2001; Ritzel et al. 2001).

ENT1 expression is high in the frontal and the parietal cortices, whereas the occipital and temporal lobe shows the highest ENT3 activity and high or intermediate ENT4 activity (Table 29.1). Intermediate or low ENT3 and ENT4 density occurs in the frontal and parietal lobes. Low levels of ENT1 expression are found in the medulla oblongata and the pons, whereas these brain areas show high to intermediate ENT2 expression. ENT2 expression is low in cortical areas and the basal ganglia. All ENT transporters are expressed at intermediate levels in the thalamus. The hippocampus shows low or intermediate ENT levels with the exception of ENT4, which is expressed at high levels in this brain area.

CNT transporters are also widely distributed in the human brain. Relatively high expression of CNT subtypes (CNT1, CNT2, and CNT3) occurs in the cerebellum, putamen, hippocampus, and medulla oblongata (Table 29.1).

\subsubsection{Distribution of Nucleoside Receptors}

The distribution of adenosine receptors in the brain reflects the physiological activity and effects of Ado in brain structures, whereas changes in the density of adenosine receptors may indicate functional and pathological changes (Boison 2005; Fastbom et al. 1986, 1987; Jenner et al. 2009).

Adenosine receptors are unevenly distributed in the human brain (Fredholm et al. 2001; Jennings et al. 2001) (Table 29.1). High expression of $A_{1}$ Rs has been measured in several cerebral cortical areas and the basal ganglia. The temporal cortex, thalamus, and hippocampus contain intermediate levels of $\mathrm{A}_{1} \mathrm{Rs}$, whereas the cerebellum, midbrain, pons, and medulla oblongata show low density of this adenosine receptor type. $A_{2 A}$ Rs are expressed at high levels in the basal ganglia and high $A_{3} R$ density occurs in the cerebellum and hippocampus. In other brain areas, $A_{2 A}$ and $A_{3} R s$ are expressed at lower levels. Uniform distribution of $A_{2 B} R s$, however, has been shown to occur. 


\subsection{Implications for Therapy}

Drugs acting on the nucleoside system are widely used for therapeutic purposes (Table 29.2, Fig. 29.1). Nucleoside metabolic enzyme inhibitors are used in anticancer therapies and the treatment of gout. In addition, several different nucleoside transport inhibitors are used as coronary vasodilators. Drugs acting on adenosine receptors are also used as vasodilators and to treat cardiac arrhythmias, carcinomas, rheumatoid arthritis, acute renal failure, and asthma. In addition, some synthetic nucleosides (nucleoside drugs) are used in antiviral and anticancer therapies.

Some drugs acting on the adenosine system have already been tested for the potential to treat brain disorders (Table 29.2). Based on its distribution and physiological roles in the CNS, the adenosine system has much wider potential for the treatment of pain, movement and mood disorders, schizophrenia, epilepsy, drug addiction, insomnia, multiple sclerosis, dementias, and stroke. Guanosine and Ino may also be neuroactive purines with therapeutic potential (Deutsch et al. 2005; Schmidt et al. 2007). The recent discovery of pyrimidine nucleotide receptors and the emerging neural functions of Urd imply that this pyrimidine nucleoside could also have therapeutic applications in the future (Cansev 2006; Connolly and Duley 1999; Dobolyi et al. 2011).

In the following sections, we discuss several neurological disorders where drugs acting on the nucleoside system may have therapeutic potential (Table 29.2).

\subsubsection{Movement Disorders}

The initiation of movement is governed by the interaction of the motor cortex, the thalamus, and a circuit consisting of several members of the basal ganglia, including the striatum, globus pallidus, and substantia nigra. The underlying pathologies for Parkinson's and Huntington's diseases are loss of nigrostriatal dopaminergic cells and degeneration of GABA/enkephalin neurons projecting from the striatum to the external globus pallidus, respectively (Harris et al. 2009).

Nucleosides and nucleoside metabolic enzymes are found in brain areas involved in movement disorders (Dawson 1971; Kovács et al. 2010a; Nagata et al. 1984; Norstrand et al. 1984; Norstrand and Glantz 1980) (Table 29.1). Nucleoside transporters are present in the caudate nucleus, putamen, globus pallidus, and substantia nigra (Barnes et al. 2006; Jennings et al. 2001; Ritzel et al. 2001). Caudate nucleus, putamen, and globus pallidus contain high levels of $A_{1}$ and $A_{2 A}$ Rs (Jennings et al. 2001). In particular, striatopallidal GABAergic enkephalin-containing neurons in the basal ganglia show the highest expression of $A_{2 \mathrm{~A}}$ Rs (Durieux et al. 2011; Popoli et al. 2007). These $A_{2 A}$ Rs tightly interact structurally and functionally with the dopamine D2 receptor and have been suggested to drive striatopallidal output balance (Xu et al. 2005). 


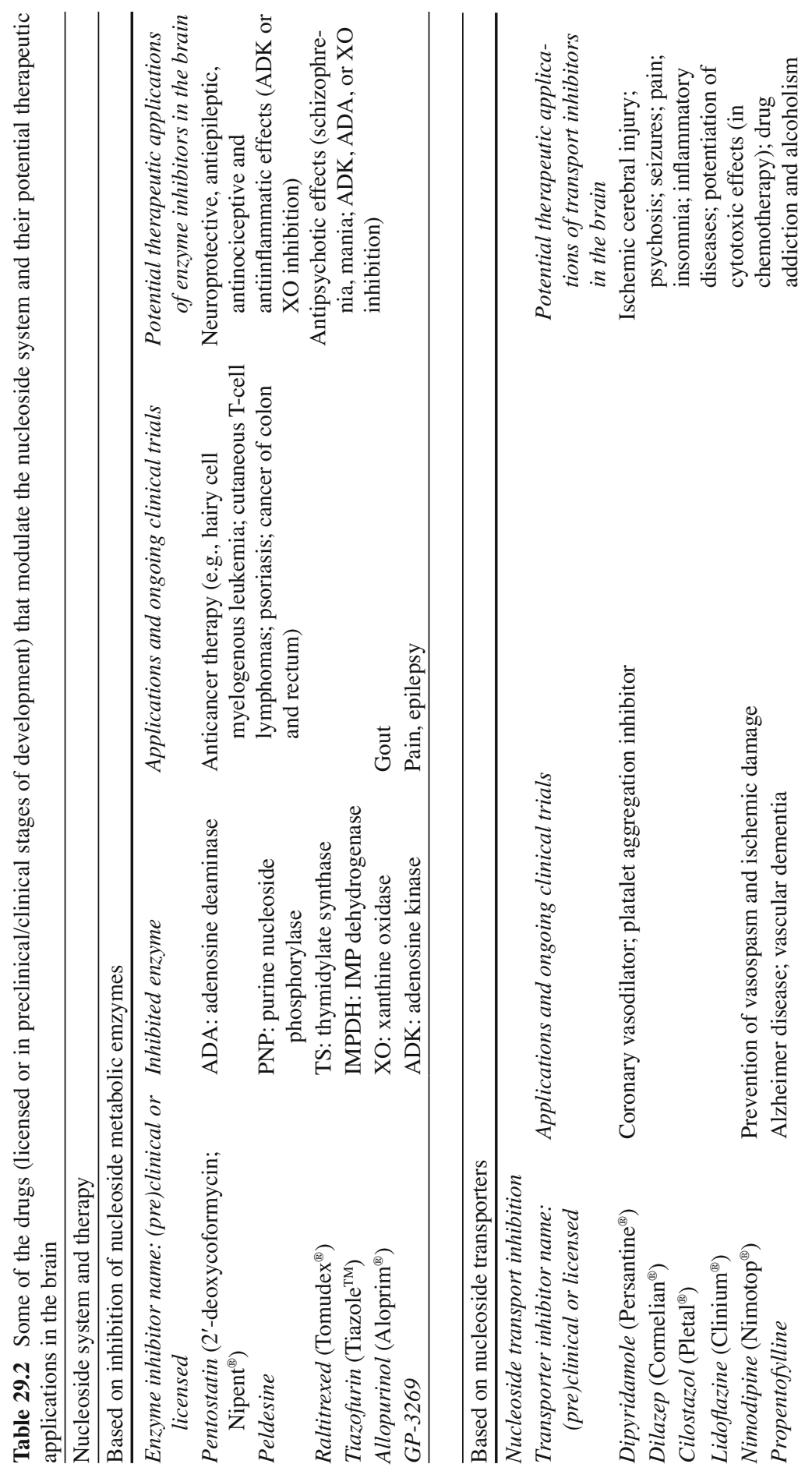




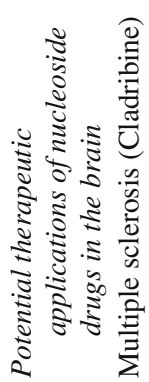

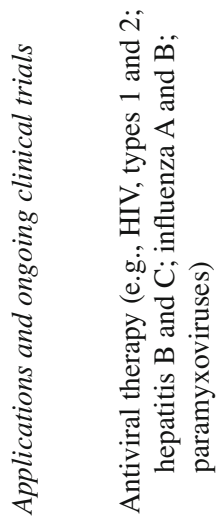

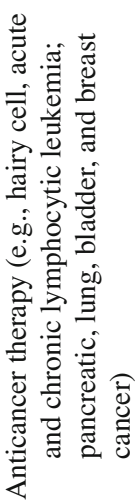

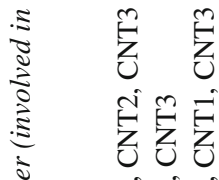

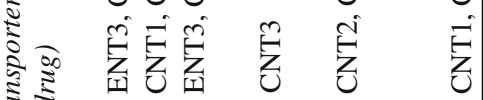
ह

ะั

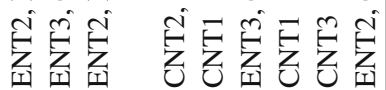

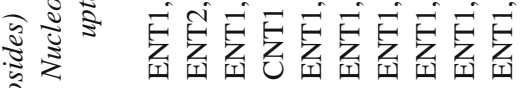

s 幽

ङ

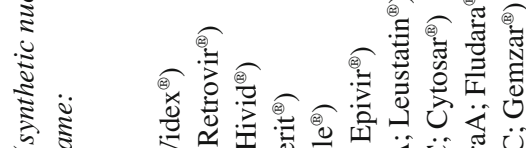

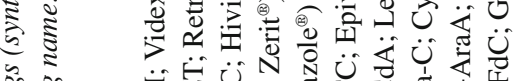

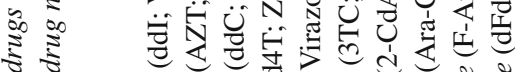

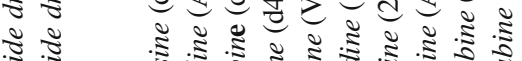

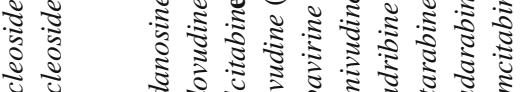

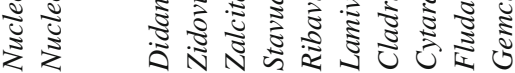

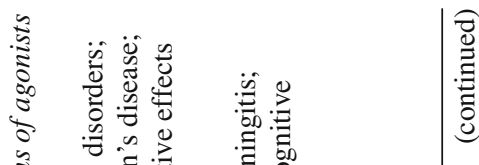

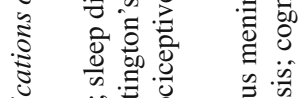

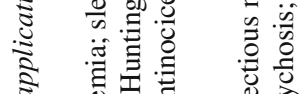

ड़

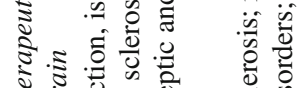

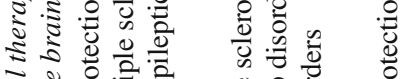

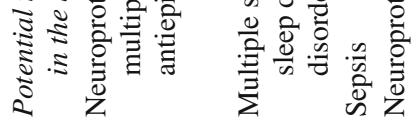

$\widetilde{\Xi}$

$\stackrel{\infty}{\Xi}$

$\stackrel{8}{3}$

छ

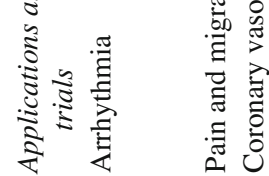

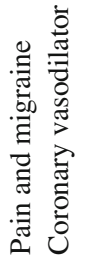

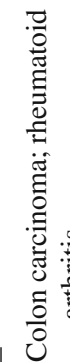

产

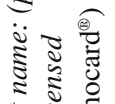

牙

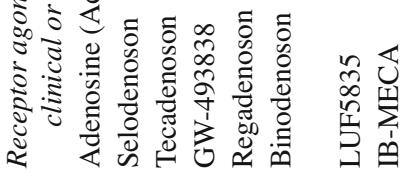

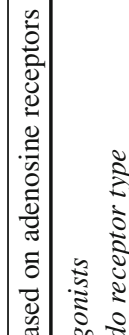

בัּ

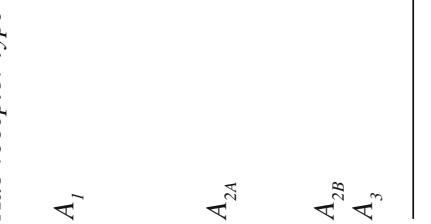




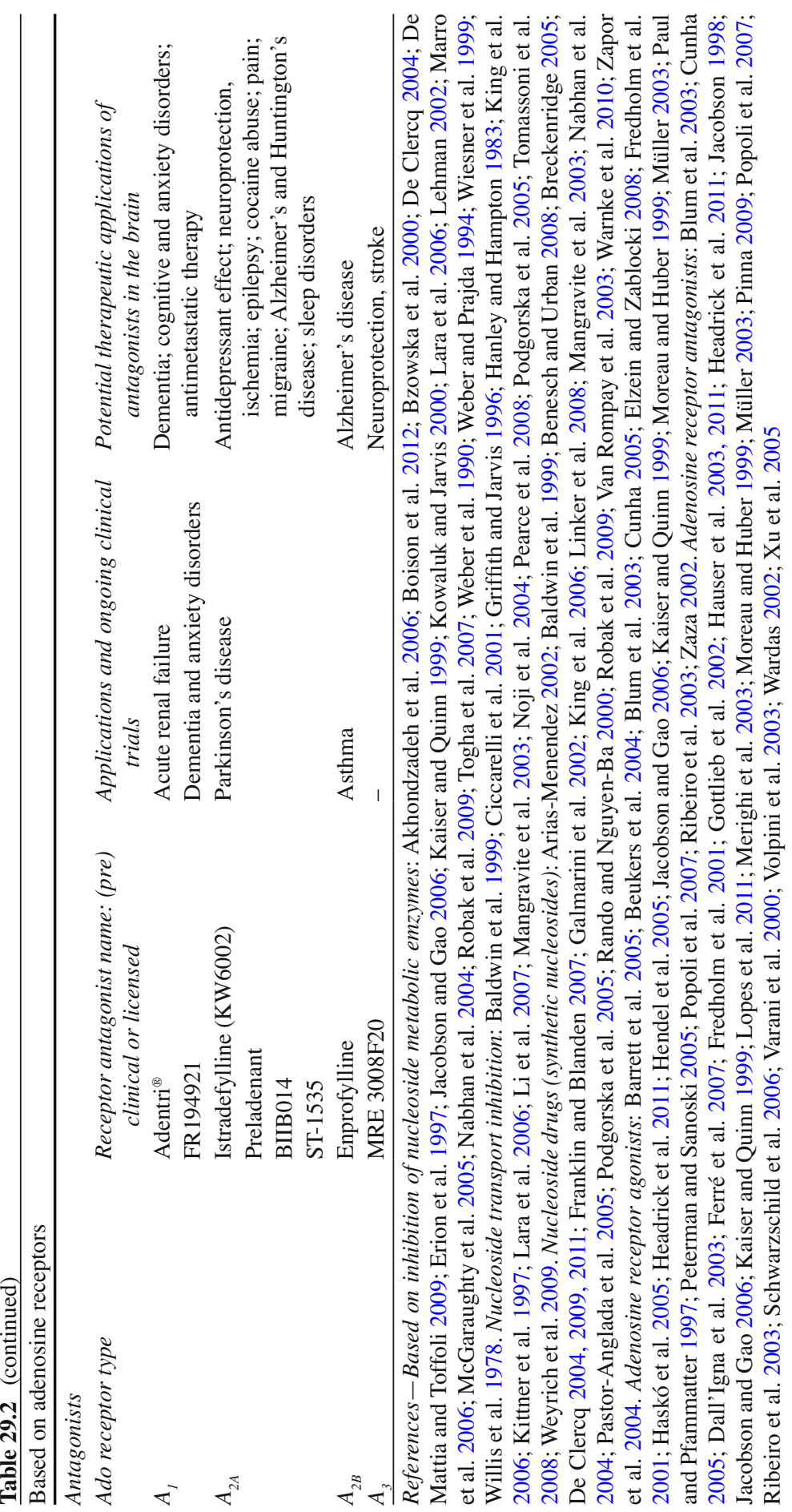


In cases of dopaminergic hypofunction, $\mathrm{A}_{2 \mathrm{~A}} \mathrm{R}$ activation contributes to the overdrive of the indirect pathway (Schiffmann et al. 2007). $A_{2 A} R$ antagonists (Table 29.2), therefore, have the potential to restore this inhibitor imbalance. Consequently, these drugs have therapeutic potential in diseases of dopaminergic hypofunction such as Parkinson's disease. Indeed, $A_{2 \mathrm{~A}} \mathrm{R}$ antagonists have been effective in a variety of animal models of Parkinson's disease (Bastia et al. 2005; Chen et al. 2001; Hodgson et al. 2010; Kanda et al. 1998, 2000). Furthermore, caffeine ameliorates the freezing of gait that occurs in Parkinson's disease patients (Kitagawa et al. 2007). A number of clinical trials are under way to evaluate the potential of $A_{2 \mathrm{~A}} \mathrm{R}$ antagonists in the treatment of Parkinson's disease (Table 29.2), and the modulation of $\mathrm{A}_{1}$ and $\mathrm{A}_{2 \mathrm{~A}}$ Rs may be effective in the treatment of Huntington's disease as well (Blum et al. 2003; Chou et al. 2005; Popoli et al. 2007).

Uridine might also be potentially effective in the treatment for Parkinson's disease. Coadministration of uridine monophosphate (UMP) and docosahexaenoic acid known to increase Urd levels and synapse formation in the brain increased striatal dopamine levels and alleviated the behavioral effects of 6-hydroxydopamine injections in a rat model of Parkinson's disease (Cansev et al. 2008).

\subsubsection{Addiction}

Although the different classes of drugs of abuse influence numerous neurotransmitter systems within the brain, all either directly or indirectly enhance the activity of the mesolimbic dopaminergic system. Within this system, ascending dopaminergic fibers project from the ventral tegmental area to the prefrontal cortex and nucleus accumbens, areas that are involved in the rewarding effects of drugs of abuse (Lajtha and Sershen 2010; Willuhn et al. 2010).

Similar to the striatum, the level of $\mathrm{A}_{2 \mathrm{~A}} \mathrm{Rs}$ is also particularly high in the nucleus accumbens (Ferré et al. 2007; Svenningsson et al. 1997), an area that contains low to intermediate levels of nucleosides (Kovács et al. 2010a) and ENT3, ENT4, and CNT3 transporters (Baldwin et al. 2005; Barnes et al. 2006; Ritzel et al. 2001) (Table 29.1). Based on the presence of nucleoside transporters in the nucleus accumbens, transport inhibitors might have therapeutic potential in the treatment of drug addiction and alcoholism (Table 29.2). Indeed, adenosine transport in the nucleus accumbens decreases following chronic administration of morphine to rats (Brundege and Williams 2002). Adenosine may inhibit the reward process via $A_{2 A}$ Rs (Baldo et al. 1999). In animal models, $A_{2 A} R$ agonists inhibit cocaine selfadministration, while antagonists reinstate this behavior (Knapp et al. 2001; Weerts and Griffiths 2003). Furthermore, mice lacking the $A_{2 A} R$ exhibit attenuated reward processes (Castane et al. 2006). Some novel human data also supports the involvement of the adenosine system in addiction. An elevated $\mathrm{A}_{2 \mathrm{~A}} \mathrm{R}$ binding affinity was found in platelets of patients suffering from pathological gambling (Martini et al. 2011). Clinical trials based on these data are expected in the near future (Lopes et al. 2011). 


\subsubsection{Pain Management}

Nociceptive impulses first reach the posterior horn of the spinal cord. From here, information is transmitted to several brain regions involved in nociception. The reticular formation regulates arousal reactions and autonomic reflexes to pain, and thalamic nuclei relay and differentiate the nociceptive stimuli. Specific nuclei of the hypothalamus mediate autonomic and neuroendocrine responses. The limbic system mediates the emotional and motivation-related aspects of nociception, while the somatosensory cortex is mainly responsible for pain differentiation and localization (Apkarian et al. 2005). Additional pathways descending from a handful of brain regions, including the periaqueductal gray, rostroventromedial medulla, lateral reticular nucleus, and some brainstem monoamine cell groups, modulate nociception (Heinricher et al. 2009).

Nucleosides and their metabolic enzymes and transporters have been observed in different regions of large anatomical structures such as the spinal cord, medulla oblongata, midbrain, thalamus, hypothalamus, and diencephalon (Table 29.1). However, there is little data on the presence of nucleoside system in the specific areas of nociceptive circuitry in the brain, and further studies are needed. Nevertheless, a significant expression of $\mathrm{A}_{1}$ Rs has been described in primary sensory neurons associated with nociceptive pathways (Lima et al. 2010).

There is a great body of evidence indicating that the activation of $\mathrm{A}_{1}$ Rs produces antinociception (Curros-Criado and Herrero 2005). Mice lacking the $A_{1} R$ exhibit hyperalgesia (Johansson et al. 2001). Consequently, drugs that target the nucleoside system have potential for the treatment of pain. GP-3269, an adenosine kinase inhibitor (Fig. 29.1), and GW-493838, an $A_{1} R$ agonist, may be useful in the treatment of pain and migraines (Elzein and Zablocki 2008; Erion et al. 1997; Kowaluk and Jarvis 2000; McGaraughty et al. 2005; Wiesner et al. 1999) (Table 29.2). Guanosine was also found to have an antinociceptive effect in mice (Schmidt et al. 2009), suggesting that it may also be a potential target for the treatment of pain.

\subsubsection{Mood Disorders}

Anxiety, panic disorder, mania, and different forms of depression do not involve major neuronal degeneration in any brain regions. Nevertheless, animal studies and various imaging techniques have identified a number of limbic brain regions that play a role in the etiology of mood disorders. These regions include the prefrontal and cingulate cortices, septohippocampal circuits, amygdala, hypothalamus, and central gray matter of the midbrain (Garakani et al. 2006; Kalia 2005). Neurons in the locus coeruleus and raphe nuclei are thought to modulate these systems, explaining the effects of noradrenergic and serotonergic drugs on mood disorders (Fava 2003).

Only some of these structures have been studied for the presence of the elements of the nucleoside system (Table 29.1). The amygdala is particularly rich in nucleosides (Kovács et al. 2010a). Intermediate or high activities of $5^{`} \mathrm{NT}$ and PNP occur in the 
amygdala and the frontal and cingulate cortices (Nagata et al. 1984; Norstrand and Glantz 1980). Intermediate/low CNT2 and CNT3 levels are also observed in the amygdala and frontal cortex (Ritzel et al. 2001). ENT4 is abundant only in the amygdala, while ENT1 is believed to be the major equilibrative nucleoside transporter subtype in the frontal cortex (Barnes et al. 2006; Jennings et al. 2001). A high level of $A_{1}$ Rs is found in the frontal cortex. Similar to the stratium (Schiffmann et al. 2007), the cortex also contains adenosine receptors both pre- and postsynaptically (Kirmse et al. 2008). Some other important brain regions, including the periaqueductal gray and monoamine systems, however, have not been systematically investigated for the presence of nucleoside metabolic enzymes and transporters. Nevertheless, the nucleoside system is expected to be a target for new drugs to treat mood disorders (Boison et al. 2012). Caffeine, a competitive antagonist of the $A_{1}$ and $\mathrm{A}_{2 \mathrm{~A}}$ Rs (Fredholm et al. 1999), promotes anxious behavior both in animal models and humans (Klein et al. 1991), and $\mathrm{A}_{2 \mathrm{~A}} \mathrm{R}$ polymorphisms are associated with increased incidence of panic disorder and depression (Hamilton et al. 2004; Lam et al. 2005; Tsai et al. 2006). In addition, mice lacking $A_{1}$ or $A_{2 A}$ Rs demonstrate anxiogenic-like behaviors (Gimenez-Llort et al. 2002; Johansson et al. 2001; Ledent et al. 1997). Indeed, the application of an $A_{1} R$ antagonist might be an effective treatment strategy for patients with anxiety disorders (Table 29.2). Allopurinol has been found to elicit therapeutic effects in the treatment of mania (Akhondzadeh et al. 2006) (Table 29.2, Fig. 29.1). Chronically administrated Guo produced anxiolytic effects in mice (Vinadé et al. 2003), suggesting a potential role of this purine nucleoside in the management of anxiety.

\subsubsection{Schizophrenia}

Pharmacological studies indicate the involvement of dopaminergic and glutamatergic neurons in the etiology of schizophrenia. A leading current hypothesis is that schizophrenia arises due to abnormalities in the dopamine-glutamate system of the corticostriatal pallidothalamic circuit, including the prefrontal cortex, nucleus accumbens, ventral tegmental area, mediodorsal thalamic nucleus, and ventral pallidum. Some drugs inducing drug dependence, probably by increasing the level of dopamine in the nucleus accumbens, also cause hallucinations suggesting that surplus dopamine may be a common ethiological factor. In addition to abnormalities in the corticostriatal system, alterations in the ventral limbic circuits of the dopamineglutamate system, including the hippocampus, enthorinal cortex, and basolateral amygdala, may also be involved (Ross et al. 2006).

There is an intermediate to high level of nucleosides in most of the brain regions implicated in schizophrenia (Kovács et al. 2010a) (Table 29.1), and the evidence suggests that schizophrenia is associated with a hypofunctioning adenosine system (Lara et al. 2006). Adenosine levels can be increased by inhibiting adenosine transporters or xanthine oxidase with dypiridamole or allopurinol, respectively (Fig. 29.1). Both of these treatments had beneficial antipsychotic effects in clinical 
trials when administered in combination with haloperidol (Akhondzadeh et al. 2000, 2005) (Table 29.2). Furthermore, psychotic symptoms in schizophrenic patients are worsened by caffeine (Lucas et al. 1990). An interaction between adenosine and the dopamine system (Ferré et al. 1997) or the glutamate system (De Mendonca et al. 1995; Gerevich et al. 2002) could be driving these effects. Indeed, $A_{2 A} R$ agonists and antagonists may have therapeutic potential for different types of psychosis (Table 29.2).

In animal models, some of the effects of haloperidol were augmented by coadministration with Urd (Agnati et al. 1989; Myers et al. 1994). Chronic Urd administration was also found to increase stereotypy scores and catalepsy induced by an acute haloperidol injection (Agnati et al. 1989). Furthermore, chronic Urd treatment reduced expression of dopamine receptors and enhanced their turnover rate in the striatum (Farabegoli et al. 1988). These data suggest that Urd coadministration might enhance the antipsychotic actions of traditional neuroleptics.

Moreover, the neuroprotective and neurotrophic effects of Guo may also be advantageous for the treatment of schizophrenia; Guo was found to attenuate hyperlocomotion induced by dizocilpine, a pharmacological model of schizophrenia, in mice (Tort et al. 2004).

\subsubsection{Epilepsy}

Epilepsy is characterized by a variety of recurrent symptoms resulting from the synchronous or sustained discharge of a group of neurons. The pathophysiology of epilepsy is poorly understood, and so far, there is no clear association between the abnormal function of a specific group of neurons and the genesis of seizures. There is some evidence, however, that the impairment of inhibitory signals, often occurring in the neocortex and hippocampus, may be primarily involved (Bertram 2009).

In the human hippocampus, ADA and GDA have intermediate activity (Dawson 1971; Norstrand et al. 1984) (Table 29.1). Adenosine and Ino levels are low, but intermediate concentrations of Guo and Urd are present (Kovács et al. 2010a). Based on their abundance, ENT4, CNT2, and CNT3 are believed to be the major nucleoside transporters in the hippocampus (Barnes et al. 2006; Ritzel et al. 2001). Furthermore, an intermediate level of $A_{1}$ and intermediate/low level of $A_{2 A} R$ is present (Jennings et al. 2001). Indeed, the interaction of Ado with the inhibitory $\mathrm{A}_{1} \mathrm{R}$ has been shown to have anticonvulsant effects in animal models (Barraco et al. 1984; Fedele et al. 2006). As $A_{1} R$ agonists have peripheral cardiac and central sedative side-effects, adenosine kinase inhibitors (Fig. 29.1) have been used to indirectly increase Ado levels (Boison 2008). These drugs were shown to have anticonvulsant properties (McGaraughty et al. 2005). In particular, GP-3269, an adenosine kinase inhibitor, was found to be useful for the treatment of epilepsy (Erion et al. 1997; Kowaluk and Jarvis 2000; McGaraughty et al. 2005; Wiesner et al. 1999) (Table 29.2). 
Recently, the distribution of $\mathrm{A}_{2 \mathrm{~A}}$ Rs in the brain has been found to be altered in an animal model of human absence epilepsy (Wistar Albino Glaxo/Rijswijk rat: WAG/ Rij), both before and after appearance of absence seizures (D'Alimonte et al. 2009). A low density of $\mathrm{A}_{1}$ Rs was also found in the thalamic reticular nucleus in another animal model of human absence epilepsy (Genetic Absence Epilepsy Rat from Strasbourg: GAERS) when compared with control animals (Ekonomou et al. 1998). These results suggest that adenosine receptors might represent a novel target for the treatment of absence epilepsy.

The anticonvulsant effects of Urd have also been hypothesized; Urd was found to reduce penicillin- (Roberts 1973; Roberts et al. 1974), pentylenetetrazole(Dwivedi and Harbison 1975), and electroconvulsion-induced (Piccoli et al. 1971) seizures in experimental rodent models of epilepsy. Indeed, Urd is released following depolarization and inhibits unit activity (Dobolyi et al. 1999, 2000). Recently, Urd has been found to act as an antiepileptogen in hippocampal kindling models (Zhao et al. 2006, 2008). In addition, Guo prevented seizures induced by quinolinic acid and other glutamatergic agents (De Oliveira et al. 2004; Schmidt et al. 2000). These data suggest that Urd and Guo also have antiepileptic potential.

\subsubsection{Insomnia}

EEG recordings and other evidence indicate that sleep affects most cortical areas. Sleep waves are generated by an interaction between cortical and thalamic circuits, including thalamic reticular and relay nuclei. Sleep states are regulated by specific brain centers, and dysfunction of these regions leads to insomnia. Serotonergic and noradrenergic projections ascending from the brainstem and histaminergic cells in the tuberomamillary nucleus promote consciousness, while the preoptic area of the hypothalamus and cholinergic neurons in the basal forebrain and tegmental nuclei of the pons promote sleep. Orexinergic cells in the lateral hypothalamus may also have important on/off functions regarding sleep states (Datta and Maclean 2007; Saper 2006). The involvement of Ado in regulating sleep has long been suspected due to the hypnotic effects of adenosine analogues (Radulovacki 1985). The distribution of Ado and its inhibitory $\mathrm{A}_{1} \mathrm{R}$ and increases of Ado levels in metabolically challenged cells are relatively ubiquitous. Furthermore, caffeine and theophylline are widely used as stimulants of the CNS. Therefore, the hypothesis emerged that, during daytime activity, ATP is degraded to adenosine, which could induce sleep. Indeed, prolonged wakefulness is known to increase Ado levels in the basal forebrain that, in turn, may decrease the activity of cholinergic cells to promote sleep (Porkka-Heiskanen and Kalinchuk 2011). A selective decrease in CNT2 mRNA levels was demonstrated in the cerebral cortex of sleep-deprived rats (GuillénGómez et al. 2004). These data suggest that adenosine receptor agonists and nucleoside transport inhibitors might be effective in the treatment of sleep disorders (Table 29.2). 
Uridine was identified as an active component of a sleep-promoting substance purified from the brainstem of sleep-deprived rats (Borbely and Tobler 1989; Inoue 1986). Infusion of Urd increased slow wave and paradoxical sleep (Honda et al. 1984). Intraperitoneally injected Urd resulted in a dose-dependent appearance of slow-wave sleep when administered shortly before onset of the dark period (Honda et al. 1985). Based on these data, drugs elevating Urd levels in the brain should be tested for the treatment of insomnia in future studies.

\subsubsection{Dementia}

Alzheimer's disease is a progressive, degenerative disease of the brain that is the most common cause of dementia in the elderly. Typical pathological features of Alzheimer's disease are neuritic plaques and neurofibrillary tangles occurring primarily in the cholinergic basal forebrain and the hippocampus, frontal, parietal, and temporal lobes of the cerebral cortex (Peskind 1996).

The cerebral cortex and the basal forebrain contain all elements of the nucleoside system (Table 29.1). Neuroprotection achieved by manipulating the brain nucleoside system could be beneficial in the treatment of dementia. Animal models implicate the involvement of $A_{2 A}$ Rs in the development Alzheimer's disease. Caffeine and $A_{2 A} R$ antagonists prevent beta-amyloid (25-35)-induced cognitive deficits in mice (Dall'Igna et al. 2007). Additionally, caffeine elevates alertness and improves cognition in humans (Eskelinen et al. 2009; Ritchie et al. 2007). These effects might be due to altered acetylcholine release by $\mathrm{A}_{2 \mathrm{~A}}$ Rs (Cunha et al. 1995; Jin and Fredholm 1997). In addition to receptor antagonists, propentofylline, an inhibitor of "es" nucleoside transporters, has established neuroprotective effects (Kittner et al. 1997), and its administration to patients with Alzheimer disease and vascular dementia resulted in functional improvements in clinical trials (Mielke et al. 1998).

Low to intermediate Ado levels but intermediate to high $\mathrm{A}_{1} \mathrm{R}$ density has been observed in brain areas implicated in Alzheimer disease (Table 29.1), and loss of human hippocampal $\mathrm{A}_{1} \mathrm{Rs}$ has been shown in dementia patients (Deckert et al. 1998). Therefore, $A_{1}$ receptor antagonists are potential targets for the treatment of dementia and cognitive disorders (Table 29.2). Administration of a nucleosidenucleotide mixture reduced memory deterioration in elderly senescence-accelerated mice (Chen et al. 2000). In addition, age-dependent alterations in the adenosine system have been found (Kovács et al. 2010b; Meyer et al. 2007). These findings suggest that Ado might participate in the pathophysiology of learning and memory disorders, as well as the normal aging process.

In animal studies, Urd was found to improve certain types of memory function (Holguin et al. 2008; Teather and Wurtman 2003, 2005, 2006). Therefore, increased Urd formation may mediate the positive effects of cytidine diphosphocholine (CDPcholine) on verbal memory in aging humans (Spiers et al. 1996). Consequently, CDP-choline and other nutritional components that increase brain Urd levels (Wurtman et al. 2000) may be important, especially during the early phases of Alzheimer's disease (Van der Beek and Kamphuis 2008; Wurtman et al. 2009). 
Recently, Guo has been found to protect against beta-amyloid-induced apoptosis (Pettifer et al. 2004). This effect appeared to be mediated by the antiapoptotic properties of Guo (Di Iorio et al. 2004). Guanosine was also found to modulate memory processes: its pretraining administration impaired retention of inhibitory avoidance responses in rats (Roesler et al. 2000). Furthermore, the amnesic effects associated with GMP pretreatment are also dependent on its conversion to Guo (Saute et al. 2006) (Fig. 29.1).

\subsubsection{Stroke}

In stroke, tissue damage is most often caused by ischemia resulting from an occluded blood vessel (Dietrich 1998). Neuroprotection by manipulation of brain nucleoside system may be beneficial in stroke victims. Adenosine and other nucleosides are elevated during ischemia (Rudolphi et al. 1992). While adenosine released from neurons or accumulated by the extracellular degradation of released ATP could reach a concentration efficient for the activation of adenosine receptors, a pathophysiological release from neurons as well as glial cells occurs during an ischemic event (Latini and Pedata 2001). Agonist stimulation of the $A_{1} R$ may inhibit excessive neuronal firing and may enhance local cerebral blood flow (O'Regan 2005), reducing brain damage following experimentally induced ischemia in animals. Indeed, lacking the $\mathrm{A}_{1}$ receptor exhibited decreased hypoxic neuroprotection in mice (Johansson et al. 2001). Thus, Ado may be involved in ischemic preconditioning, an endogenous neuroprotective mechanism (Liu et al. 2009). Consequently, drugs that act on adenosine receptors, adenosine metabolizing enzymes, and nucleoside transporters (Table 29.2, Fig. 29.1) and increase EC Ado levels could be targets for the development of clinical therapeutics suitable for treatment of ischemic brain disorders (Stone 2002; Von Lubitz 2001). Importantly, the effectiveness of all of these potential therapies may vary between patients due to differences in the spatial distribution of the nucleoside system (Table 29.1). Indeed, the nucleoside system may be modulated differently in men and women (Kovács et al. 2010b). Changes in nucleoside levels in female brain cortical samples may serve as a protective mechanism against excitotoxic insults, suggesting that several normal and pathological brain functions are based on gender-dependent nucleoside microenvironments in humans.

Other nucleosides might also have neuroprotective functions in response to ischemic injury, and increasing their expression might be beneficial both during and after an ischemic attack. In animal models, Guo had neuroprotective effects in both in vitro and in vivo stroke models (Chang et al. 2008). Inosine was also shown to reduce ischemic brain injury in rats (Shen et al. 2005). Inosine and Guo preserved the viability of cultured astrocytes, neurons (Jurkowitz et al. 1998; Litsky et al. 1999), and brain slices maintained under hypoxic or hypoglycemic conditions (Frizzo et al. 2002). The potential neuroprotective effects of Guo are also supported by the finding that neuronal and astrocytic cell cultures are able to release Guo and Ado under both basal and ischemic conditions (Ciccarelli et al. 2001). 


\subsubsection{Multiple Sclerosis}

Multiple sclerosis is characterized by multiple symptoms of brain and spinal cord dysfunction that reflect degeneration of particular areas of the nervous system that are involved. The affected regions vary between patients and are not specific to the disease. The pathological hallmark is inflammatory demyelination and axonal lesions. Inflammation is primarily driven by autoreactive lymphocytes, which recruit immune cells, such as macrophages, causing tissue damage (Hauser and Oksenberg 2006).

A synthetic nucleoside, cladribine, was shown to be effective in the treatment of multiple sclerosis (Table 29.2). The biologic activity of cladribine is dependent on the preferential accumulation of cladribine phosphates in cells with a high intracellular ratio of deoxycytidine kinase to $5^{\prime} \mathrm{NT}$. Cladribine-phosphates incorporate into DNA, interfering with DNA synthesis and repair and inhibiting enzymes involved in DNA metabolism, such as DNA polymerase and ribonucleotide reductase. This, in turn, leads to DNA strand breaks and, ultimately, cell death (Leist and Weissert 2011). Because activated macrophages, but not neuronal and glial cells, have a high deoxycytidine kinase to 5'NT ratio (Ceruti et al. 2000; Nagata et al. 1984), cladribine can selectively inhibit the damaging inflammatory process that occurs in multiple sclerosis.

Inosine may also have beneficial effects in the treatment of multiple sclerosis (Markowitz et al. 2009). These data suggest that regional differences in nucleoside system may influence the pathological processes of multiple sclerosis, but further studies are needed to confirm this hypothesis.

In conclusion, the current data suggest that nucleoside system offers promising drug targets for the treatment of a variety of brain disorders, including Alzheimer's, Huntington's and Parkinson's diseases, epilepsy, and schizophrenia. Unfortunately, although the nucleoside system has been implicated in the development and treatment of a number of brain disorders, a systematic investigation of the nucleoside system in most brain areas has not yet been performed. These data are needed to elucidate therapeutic strategies driven by the anatomical distribution of nucleoside system. In addition, attention must be given to the effects of gender and age in future studies. These data are eagerly awaited and will help form the foundation for studies of the physiological and pathophysiological functions of nucleosides and for the development of effective treatments for several CNS diseases.

Acknowledgments This work was supported by the Scientific Foundation of NYME SEK/ NYME SEK TTK (2010-2011) Hungary (Zsolt Kovács) and the OTKA NNF2 85612 Research Grant as well as the Bolyai János Grant of the Hungarian Academy of Sciences (Arpád Dobolyi). Conflict of interest: All authors declare no conflicts of interest. 


\section{References}

Agnati LF, Fuxe K, Ruggeri M, Merlo Pich E, Benfenati F, Volterra V, Ungerstedt U, Zini I (1989) Effects of chronic treatment with uridine on striatal dopamine release and dopamine related behaviours in the absence or the presence of chronic treatment with haloperidol. Neurochem Int 15:107-113

Akhondzadeh S, Shasavand E, Jamilian H, Shabestari O, Kamalipour A (2000) Dipyridamole in the treatment of schizophrenia: adenosine-dopamine receptor interactions. J Clin Pharm Ther 25:131-137

Akhondzadeh S, Safarcherati A, Amini H (2005) Beneficial antipsychotic effects of allopurinol as add-on therapy for schizophrenia: a double blind, randomized and placebo controlled trial. Prog Neuropsychopharmacol Biol Psychiatry 29:253-259

Akhondzadeh S, Milajerdi MR, Amini H, Tehrani-Doost M (2006) Allopurinol as an adjunct to lithium and haloperidol for treatment of patients with acute mania: a double-blind, randomized, placebo-controlled trial. Bipolar Disord 8:485-489

Apkarian AV, Bushnell MC, Treede RD, Zubieta JK (2005) Human brain mechanisms of pain perception and regulation in health and disease. Eur J Pain 9:463-484

Arias-Menendez L (2002) Targeting HIV: antiretroviral therapy and development of drug resistance. Trends Pharmacol Sci 23:381-388

Baldo BA, Koob GF, Markou A (1999) Role of adenosine A2 receptors in brain stimulation reward under baseline conditions and during cocaine withdrawal in rats. J Neurosci 19:11017-11026

Baldwin SA, Mackey JR, Cass CE, Young JD (1999) Nucleoside transporters: molecular biology and implications for therapeutic development. Mol Med Today 5:216-224

Baldwin SA, Yao SYM, Hyde RJ, Ng AML, Foppolo S, Barnes K, Ritzel MWL, Cass CE, Young JD (2005) Functional characterization of novel human and mouse equilibrative nucleoside transporters (hENT3 and mENT3) located in intracellular membranes. J Biol Chem 280:15880-15887

Barnes K, Dobrzynski H, Foppolo S, Beal PR, Ismat F, Scullion ER, Sun L, Tellez J, Ritzel MW, Claycomb WC, Cass CE, Young JD, Billeter-Clark R, Boyett MR, Baldwin SA (2006) Distribution and functional characterization of equilibrative nucleoside transporter-4, a novel cardiac adenosine transporter activated at acidic $\mathrm{pH}$. Circ Res 99:510-519

Barraco RA, Swanson TH, Phillis JW, Berman RF (1984) Anticonvulsant effects of adenosine analogues on amygdaloid-kindled seizures in rats. Neurosci Lett 46:317-322

Barrett RJ, Lamson MJ, Johnson J, Smith WB (2005) Pharmacokinetics and safety of binodenoson after intravenous dose escalation in healthy volunteers. J Nucl Cardiol 12:166-171

Bastia E, Xu YH, Scibelli AC, Day YJ, Linden J, Chen JF, Schwarzschild MA (2005) A crucial role for forebrain adenosine $\mathrm{A}(2 \mathrm{~A})$ receptors in amphetamine sensitization. Neuropsychopharmacology 30:891-900

Bender E, Buist A, Jurzak M, Langlois X, Baggerman G, Verhasselt P, Ercken M, Guo HQ, Wintmolders C, Van den Wyngaert I, Van Oers I, Schoofs L, Luyten W (2002) Characterization of an orphan $\mathrm{G}$ protein-coupled receptor localized in the dorsal root ganglia reveals adenine as a signaling molecule. Proc Natl Acad Sci USA 99:8573-8578

Benesch M, Urban C (2008) Liposomal cytarabine for leukemic and lymphomatous meningitis: recent developments. Expert Opin Pharmacother 9:301-309

Berne RM, Rubio R, Curnish RR (1974) Release of adenosine from ischemic brain: effect on cerebral vascular resistance and incorporation into cerebral adenine nucleotides. Circ Res $35: 262-271$

Bertram EH (2009) Temporal lobe epilepsy: where do the seizures really begin? Epilepsy Behav 14(Suppl 1):32-37

Beukers MW, Chang LC, von Frijtag Drabbe Kunzel JK, Mulder-Krieger T, Spanjersberg RF, Brussee J, Ijzerman AP (2004) New, non-adenosine, high-potency agonists for the human adenosine $\mathrm{A} 2 \mathrm{~B}$ receptor with an improved selectivity profile compared to the reference agonist N-ethylcarboxamidoadenosine. J Med Chem 47:3707-3709 
Bjerring PN, Hauerberg J, Jørgensen L, Frederiksen HJ, Tofteng F, Hansen BA, Larsen FS (2010) Brain hypoxanthine concentration correlates to lactate/pyruvate ratio but not intracranial pressure in patients with acute liver failure. J Hepatol 53:1054-1058

Blum D, Hourez R, Galas MC, Popoli P, Schiffmann SN (2003) Adenosine receptors and Huntington's disease: implications for pathogenesis and therapeutics. Lancet Neurol 2:366-374

Boison D (2005) Adenosine and epilepsy: from therapeutic rationale to new therapeutic strategies. Neuroscientist 11:25-36

Boison D (2008) The adenosine kinase hypothesis of epileptogenesis. Prog Neurobiol 84:249-262

Boison D (2011) Modulators of nucleoside metabolism in the therapy of brain diseases. Curr Top Med Chem 11:1068-1086

Boison D, Singer P, Shen HY, Feldon J, Yee BK (2012) Adenosine hypothesis of schizophreniaOpportunities for pharmacotherapy. Neuropharmacology 62:1527-1543

Borbely AA, Tobler I (1989) Endogenous sleep-promoting substances and sleep regulation. Physiol Rev 69:605-670

Borrmann T, Abdelrahman A, Volpini R, Lambertucci C, Alksnis E, Gorzalka S, Knospe M, Schiedel AC, Cristalli G, Müller CE (2009) Structure-activity relationships of adenine and deazaadenine derivatives as ligands for adenine receptors, a new purinergic receptor family. J Med Chem 52:5974-5989

Bowley MP, Drevets WC, Öngür D, Price JL (2002) Low glial numbers in the amygdala in major depressive disorder. Biol Psychiatry 52:404-412

Brauch RA, Adnan El-Masri M, Parker JC Jr, El-Mallakh RS (2006) Glial cell number and neuron/ glial cell ratios in postmortem brains of bipolar individuals. J Affect Disord 91:87-90

Breckenridge A (2005) Pharmacology of drugs for HIV. Medicine 33:30-31

Brundege JM, Williams JT (2002) Increase in adenosine sensitivity in the nucleus accumbens following chronic morphine treatment. J Neurophysiol 87:1369-1375

Burnstock G, Fredholm BB, Verkhratsky A (2011) Adenosine and ATP receptors in the brain. Curr Top Med Chem 11:973-1011

Bzowska A, Kulikowska E, Shugar D (2000) Purine nucleoside phosphorylases: properties, functions, and clinical aspects. Pharmacol Therapeut 88:349-425

Cansev M (2006) Uridine and cytidine in the brain: their transport and utilization. Brain Res Rev 52:389-397

Cansev M, Ulus IH, Wang L, Maher TJ, Wurtman RJ (2008) Restorative effects of uridine plus docosahexaenoic acid in a rat model of Parkinson's disease. Neurosci Res 62:206-209

Castane A, Soria G, Ledent C, Maldonado R, Valverde O (2006) Attenuation of nicotine-induced rewarding effects in A2A knockout mice. Neuropharmacology 51:631-640

Ceballos G, Tuttle JB, Rubio R (1994) Differential distribution of purine metabolizing enzymes between glia and neurons. J Neurochem 62:1144-1153

Ceruti S, Franceschi C, Barbieri D, Malorni W, Camurri A, Giammarioli AM, Ambrosini A, Racagni G, Cattabeni F, Abbracchio MP (2000) Apoptosis induced by 2-chloro-adenosine and 2-chloro-2'-deoxy-adenosine in a human astrocytoma cell line: differential mechanisms and possible clinical relevance. J Neurosci Res 60:388-400

Chang R, Algird A, Bau C, Rathbone MP, Jiang S (2008) Neuroprotective effects of guanosine on stroke models in vitro and in vivo. Neurosci Lett 431:101-105

Chen TH, Wang MF, Liang YF, Komatsu T, Chan YC, Chung SY, Yamamoto S (2000) A nucleoside-nucleotide mixture may reduce memory deterioration in old senescence-accelerated mice. J Nutr 130:3085-3089

Chen JF, Xu K, Petzer JP, Staal R, Xu YH, Beilstein M, Sonsalla PK, Castagnoli K, Castagnoli N Jr, Schwarzschild MA (2001) Neuroprotection by caffeine and A(2A) adenosine receptor inactivation in a model of Parkinson's disease. J Neurosci 21:RC143

Chou SY, Lee YC, Chen HM, Chiang MC, Lai HL, Chang HH, Wu YC, Sun CN, Chien CL, Lin YS, Wang SC, Tung YY, Chang C, Chern Y (2005) CGS21680 attenuates symptoms of Huntington's disease in a transgenic mouse model. J Neurochem 93:310-320 
Ciccarelli R, Ballerini P, Sabatino G, Rathbone MP, D’Onofrio M, Caciagli F, Di Iorio P (2001) Involvement of astrocytes in purine-mediated reparative processes in the brain. Int $\mathrm{J}$ Dev Neurosci 19:395-414

Connolly GP, Duley JA (1999) Uridine and its nucleotides: biological actions, therapeutic potentials. Trends Pharmacol Sci 20:218-225

Cornfield LJ, Hu S, Hurt SD, Sills MA (1992) [3 H]2-phenylaminoadenosine ([3 H]CV 1808) labels a novel adenosine receptor in rat brain. J Pharmacol Exp Ther 263:552-561

Cunha RA (2005) Neuroprotection by adenosine in the brain: from A(1) receptor activation to A (2A) receptor blockade. Purinergic Signal 1:111-134

Cunha RA, Johansson B, Fredholm BB, Ribeiro JA, Sebastiao AM (1995) Adenosine A2A receptors stimulate acetylcholine release from nerve terminals of the rat hippocampus. Neurosci Lett 196:41-44

Curros-Criado MM, Herrero JF (2005) The antinociceptive effects of the systemic adenosine A1 receptor agonist $\mathrm{CPA}$ in the absence and in the presence of spinal cord sensitization. Pharmacol Biochem Behav 82:721-726

D’Alimonte I, D'Auro M, Citraro R, Biagioni F, Jiang S, Nargi E, Buccella S, Di Iorio P, Giuliani P, Ballerini P, Caciagli F, Russo E, De Sarro G, Ciccarelli R (2009) Altered distribution and function of A2A adenosine receptors in the brain of WAG/Rij rats with genetic absence epilepsy, before and after appearance of the disease. Eur J Neurosci 30:1023-1035

Dall'Igna OP, Porciúncula LO, Souza DO, Cunha RA, Lara DR (2003) Neuroprotection by caffeine and adenosine A2A receptor blockade of beta-amyloid neurotoxicity. Br J Pharmacol 138:1207-1209

Dall'Igna OP, Fett P, Gomes MW, Souza DO, Cunha RA, Lara DR (2007) Caffeine and adenosine $\mathrm{A}(2 \mathrm{a})$ receptor antagonists prevent beta-amyloid (25-35)-induced cognitive deficits in mice. Exp Neurol 203:241-245

Datta S, Maclean RR (2007) Neurobiological mechanisms for the regulation of mammalian sleepwake behavior: reinterpretation of historical evidence and inclusion of contemporary cellular and molecular evidence. Neurosci Biobehav Rev 31:775-824

Dawson DM (1971) Absence of guanine deaminase from cerebellum. Neurology 21:621-626

De Clercq E (2004) Antiviral drugs in current clinical use. J Clin Virol 30:115-133

De Clercq E (2009) Anti-HIV drugs: 25 compounds approved within 25 years after the discovery of HIV. Int J Antimicrob Agents 33:307-320

De Clercq E (2011) A 40-year journey in search of selective antiviral chemotherapy. Annu Rev Pharmacol Toxicol 51:1-24

De Mattia E, Toffoli G (2009) C677T and A1298C MTHFR polymorphisms, a challenge for antifolate and fluoropyrimidine-based therapy personalisation. Eur J Cancer 45:1333-1351

De Mendonca A, Sebastiao AM, Ribeiro JA (1995) Inhibition of NMDA receptor-mediated currents in isolated rat hippocampal neurones by adenosine A1 receptor activation. Neuroreport 6:1097-1100

De Oliveira DL, Horn JF, Rodrigues JM, Frizzo ME, Moriguchi E, Souza DO, Wofchuk S (2004) Quinolinic acid promotes seizures and decreases glutamate uptake in young rats: reversal by orally administered guanosine. Brain Res 1018:48-54

Deckert J, Abel F, Kunig G, Hartmann J, Senitz D, Maier H, Ransmayr G, Riederer P (1998) Loss of human hippocampal adenosine $\mathrm{A}_{1}$ receptors in dementia: evidence for lack of specificity. Neurosci Lett 244:1-4

Deutsch SI, Long KD, Rosse RB, Mastropaolo J, Eller J (2005) Hypothesized deficiency of guanine-based purines may contribute to abnormalities of neurodevelopment, neuromodulation, and neurotransmission in Lesch-Nyhan syndrome. Clin Neuropharmacol 28:28-37

Di Iorio P, Ballerini P, Traversa U, Nicoletti F, D'Alimonte I, Kleywegt S, Werstiuk ES, Rathbone MP, Caciagli F, Ciccarelli R (2004) The antiapoptotic effect of guanosine is mediated by the activation of the PI 3-kinase/AKT/PKB pathway in cultured rat astrocytes. Glia 46:356-368

Dietrich WD (1998) Neurobiology of stroke. Int Rev Neurobiol 42:55-101

Dobolyi A, Szikra T, Kekesi AK, Kovacs Z, Juhasz G (1999) Uridine is released by depolarization and inhibits unit activity in the rat hippocampus. Neuroreport 10:3049-3053 
Dobolyi A, Reichart A, Szikra T, Nyitrai G, Kekesi KA, Juhasz G (2000) Sustained depolarisation induces changes in the extracellular concentrations of purine and pyrimidine nucleosides in the rat thalamus. Neurochem Int 37:71-79

Dobolyi A, Juhasz G, Kovacs Z, Kardos J (2011) Uridine function in the central nervous system. Curr Top Med Chem 11:1058-1067

Durieux PF, Schiffmann SN, de Kerchove d'Exaerde A (2011) Targeting neuronal populations of the striatum. Front Neuroanat 5:40

Dwivedi C, Harbison RD (1975) Anticonvulsant activities of delta-8 and delta-9 tetrahydrocannabinol and uridine. Toxicol Appl Pharmacol 31:452-458

Eells JT, Spector R (1983) Purine and pyrimidine base and nucleoside concentrations in human cerebrospinal fluid and plasma. Neurochem Res 8:1451-1457

Ekonomou A, Angelatou F, Vergnes M, Kostopoulos G (1998) Lower density of A1 adenosine receptors in nucleus reticularis thalami in rats with genetic absence epilepsy. Neuroreport 9:2135-2140

Elzein E, Zablocki J (2008) A1 adenosine receptor agonists and their potential therapeutic applications. Expert Opin Investig Drugs 17:1901-1910

Erion MD, Ugarkar BG, Dare J, Castellino AJ, Fujitaki JM, Dixon R, Appleman JR, Wiesner JB (1997) Design, synthesis and anticonvulsant activity of the potent adenosine kinase inhibitor GP3269. Nucleos Nucleot 16:1013-1021

Eskelinen MH, Ngandu T, Tuomilehto J, Soininen H, Kivipelto M (2009) Midlife coffee and tea drinking and the risk of late-life dementia: a population-based CAIDE study. J Alzheimers Dis 16:85-91

Farabegoli C, Merlo Pich E, Cimino M, Agnati LF, Fuxe K (1988) Chronic uridine treatment reduces the level of $[3 \mathrm{H}]$ spiperone-labelled dopamine receptors and enhances their turnover rate in striatum of young rats: relationship to dopamine-dependent behaviours. Acta Physiol Scand 132:209-216

Fastbom J, Pazos A, Probst A, Palacios JM (1986) Adenosine A1 receptors is human brain: characterisation and autoradiographic visualization. Neurosci Lett 65:127-132

Fastbom J, Pazos A, Palacios JM (1987) The distribution of adenosine A1 receptors and 5'-nucleotidase is the brain of some commonly used experimental animals. Neuroscience 22:813-826

Fava M (2003) The role of the serotonergic and noradrenergic neurotransmitter systems in the treatment of psychological and physical symptoms of depression. J Clin Psychiatry 64(Suppl 13):26-29

Fedele DE, Li T, Lan JQ, Fredholm BB, Boison D (2006) Adenosine A1 receptors are crucial in keeping an epileptic focus localized. Exp Neurol 200:184-190

Fernández JR, Sweet ES, Welsh WJ, Firestein BL (2010) Identification of small molecule compounds with higher binding affinity to guanine deaminase (cypin) than guanine. Bioorg Med Chem 18:6748-6755

Ferré S, Fredholm BB, Morelli M, Popoli P, Fuxe K (1997) Adenosine-dopamine receptor-receptor interactions as an integrative mechanism in the basal ganglia. Trends Neurosci 20:482-487

Ferré S, Diamond I, Goldberg SR, Yao L, Hourani SM, Huang ZL, Urade Y, Kitchen I (2007) Adenosine A2A receptors in ventral striatum, hypothalamus and nociceptive circuitry implications for drug addiction, sleep and pain. Prog Neurobiol 83:332-347

Fields RD, Burnstock G (2006) Purinergic signalling in neuron-glia interactions. Nat Rev Neurosci 7:423-436

Firestein BL, Brenman JE, Aoki C, Sanchez-Perez AM, El-Husseini AE, Bredt DS (1999) Cypin: a cytosolic regulator of PSD-95 postsynaptic targeting. Neuron 24:659-672

Franklin A, Blanden RV (2007) Potential inhibition of somatic hypermutation by nucleoside analogues. Mol Immunol 44:666-669

Fredholm BB, Battig K, Holmen J, Nehlig A, Zvartau EE (1999) Actions of caffeine in the brain with special reference to factors that contribute to its widespread use. Pharmacol Rev 51:83-133

Fredholm BB, Ijzerman AP, Jacobson KA, Klotz KN, Linden J (2001) International Union of Pharmacology. XXV. Nomenclature and classification of adenosine receptors. Pharmacol Rev 53:527-552 
Frizzo ME, Lara DR, Prokopiuk Ade S, Vargas CR, Salbego CG, Wajner M, Souza DO (2002) Guanosine enhances glutamate uptake in brain cortical slices at normal and excitotoxic conditions. Cell Mol Neurobiol 22:353-363

Galmarini CM, Mackey JR, Dumontet C (2002) Nucleoside analogues and nucleobases in cancer treatment. Lancet Oncol 3:415-424

Garakani A, Mathew SJ, Charney DS (2006) Neurobiology of anxiety disorders and implications for treatment. Mt Sinai J Med 73:941-949

Geiger JD, Nagy JI (1986) Distribution of adenosine deaminase activity in rat brain and spinal cord. J Neurosci 6:2707-2714

Gerevich Z, Wirkner K, Illes P (2002) Adenosine A2A receptors inhibit the N-methyl-D-aspartate component of excitatory synaptic currents in rat striatal neurons. Eur J Pharmacol 451:161-164

Gimenez-Llort L, Fernandez-Teruel A, Escorihuela RM, Fredholm BB, Tobena A, Pekny M, Johansson B (2002) Mice lacking the adenosine A1 receptor are anxious and aggressive, but are normal learners with reduced muscle strength and survival rate. Eur J Neurosci 16:547-550

Gottlieb SS, Brater DC, Thomas I, Havranek E, Bourge R, Goldman S, Dyer F, Gomez M, Bennett D, Ticho B, Beckman E, Abraham WT (2002) BG9719 (CVT-124), an A1 adenosine receptor antagonist, protects against the decline in renal function observed with diuretic therapy. Circulation 105:1348-1353

Gracia E, Cortés A, Meana JJ, García-Sevilla J, Herhsfield MS, Canela EI, Mallol J, Lluís C, Franco R, Casadó V (2008) Human adenosine deaminase as an allosteric modulator of human $\mathrm{A}(1)$ adenosine receptor: abolishment of negative cooperativity for $[\mathrm{H}](\mathrm{R})$-pia binding to the caudate nucleus. J Neurochem 107:161-170

Griffith GA, Jarvis SM (1996) Nucleoside and nucleobase transport systems of mammalian cells. Biochim Biophys Acta 1286:153-181

Guillén-Gómez E, Calbet M, Casado J, de Lecea L, Soriano E, Pastor-Anglada M, Burgaya F (2004) Distribution of CNT2 and ENT1 transcripts in rat brain: selective decrease of CNT2 mRNA in the cerebral cortex of sleep-deprived rats. J Neurochem 90:883-893

Hagberg H, Andersson P, Lacarewicz J, Jacobson I, Butcher S, Sandberg M (1987) Extracellular adenosine, inosine, hypoxanthine, and xanthine in relation to tissue nucleotides and purines in rat striatum during transient ischemia. J Neurochem 49:227-231

Hamilton SP, Slager SL, De Leon AB, Heiman GA, Klein DF, Hodge SE, Weissman MM, Fyer AJ, Knowles JA (2004) Evidence for genetic linkage between a polymorphism in the adenosine 2A receptor and panic disorder. Neuropsychopharmacology 29:558-565

Hanley SP, Hampton JR (1983) Ventricular arrhythmias associated with lidoflazine: side-effects observed in a randomized trial. Eur Heart J 4:889-893

Harper DG, Stopa EG, Kuo-Leblanc V, McKee AC, Asayama K, Volicer L, Kowall N, Satlin A (2008) Dorsomedial SCN neuronal subpopulations subserve different functions in human dementia. Brain 131:1609-1617

Harris MK, Shneyder N, Borazanci A, Korniychuk E, Kelley RE, Minagar A (2009) Movement disorders. Med Clin North Am 93:371-388

Haskó G, Sitkovsky MV, Szabó C (2004) Immunomodulatory and neuroprotective effects of inosine. Trends Pharmacol Sci 25:152-157

Haskó G, Pacher P, Vizi ES, Illes P (2005) Adenosine receptor signaling in the brain immune system. Trends Pharmacol Sci 26:511-516

Hauser SL, Oksenberg JR (2006) The neurobiology of multiple sclerosis: genes, inflammation, and neurodegeneration. Neuron 52:61-76

Hauser RA, Hubble JP, Truong DD (2003) Randomized trial of the adenosine A(2A) receptor antagonist istradefylline in advanced PD. Neurology 61:286-287

Hauser RA, Cantillon M, Pourcher E, Micheli F, Mok V, Onofrj M, Huyck S, Wolski K (2011) Preladenant in patients with Parkinson's disease and motor fluctuations: a phase 2, doubleblind, randomised trial. Lancet Neurol 10:221-229

Headrick JP, Peart JN, Reichelt ME, Haseler LJ (2011) Adenosine and its receptors in the heart: regulation, retaliation and adaptation. Biochim Biophys Acta 1808:1413-1428 
Heinricher MM, Tavares I, Leith JL, Lumb BM (2009) Descending control of nociception: specificity, recruitment and plasticity. Brain Res Rev 60:214-225

Hendel RC, Bateman TM, Cerqueira MD, Iskandrian AE, Leppo JA, Blackburn B, Mahmarian JJ (2005) Initial clinical experience with regadenoson, a novel selective A2A agonist for pharmacologic stress single-photon emission computed tomography myocardial perfusion imaging. J Am Coll Cardiol 46:2076-2078

Hodgson RA, Bedard PJ, Varty GB, Kazdoba TM, Di Paolo T, Grzelak ME, Pond AJ, Hadjtahar A, Belanger N, Gregoire L, Dare A, Neustadt BR, Stamford AW, Hunter JC (2010) Preladenant, a selective $\mathrm{A}(2 \mathrm{~A})$ receptor antagonist, is active in primate models of movement disorders. Exp Neurol 225:384-390

Holguin S, Martinez J, Chow C, Wurtman R (2008) Dietary uridine enhances the improvement in learning and memory produced by administering DHA to gerbils. FASEB J 22:3938-3946

Honda K, Komoda Y, Nishida S, Nagasaki H, Higashi A, Uchizono K, Inoue S (1984) Uridine as an active component of sleep-promoting substance: its effects on nocturnal sleep in rats. Neurosci Res 1:243-252

Honda K, Okano Y, Komoda Y, Inoue S (1985) Sleep-promoting effects of intraperitoneally administered uridine in unrestrained rats. Neurosci Lett 62:137-141

Huang ZL, Urade Y, Hayaishi O (2011) The role of adenosine in the regulation of sleep. Curr Top Med Chem 11:1047-1057

Inoue S (1986) Sleep and sleep substances. Brain Dev 8:469-473

Ipata PL, Camici M, Micheli V, Tozzi MG (2011) Metabolic network of nucleosides in the brain. Curr Top Med Chem 11:909-922

Jacobson KA (1998) Adenosine A3 receptors: novel ligands and paradoxical effects. Trends Pharmacol Sci 19:184-191

Jacobson KA, Gao ZG (2006) Adenosine receptors as therapeutic targets. Nat Rev Drug Discov 5:247-264

Jenner P, Mori A, Hauser R, Morelli M, Fredholm BB, Chen JF (2009) Adenosine, adenosine A antagonists, and Parkinson's disease. Parkinsonism Relat Disord 15:406-413

Jennings LL, Hao C, Cabrita MA, Vickers MF, Baldwin SA, Young J, Cass CE (2001) Distinct regional distribution of human equilibrative nucleoside transporter proteins 1 and 2 (hENT1 and hENT2) in the central nervous system. Neuropharmacology 40:722-731

Jin S, Fredholm BB (1997) Adenosine A2A receptor stimulation increases release of acetylcholine from rat hippocampus but not striatum, and does not affect catecholamine release. Naunyn Schmiedeberg's Arch Pharmacol 355:48-56

Johansson B, Halldner L, Dunwiddie TV, Masino SA, Poelchen W, Gimenez-Llort L, Escorihuela RM, Fernandez-Teruel A, Wiesenfeld-Hallin Z, Xu XJ, Hårdemark A, Betsholtz C, Herlenius E, Fredholm BB (2001) Hyperalgesia, anxiety, and decreased hypoxic neuroprotection in mice lacking the adenosine A1 receptor. Proc Natl Acad Sci USA 98:9407-9412

Jurkowitz MS, Litsky ML, Browning MJ, Hohl CM (1998) Adenosine, inosine, and guanosine protect glial cells during glucose deprivation and mitochondrial inhibition: correlation between protection and ATP preservation. J Neurochem 71:535-548

Kaiser SM, Quinn RJ (1999) Adenosine receptors as potential therapeutic targets. Drug Discov Today 4:542-551

Kalia M (2005) Neurobiological basis of depression: an update. Metabolism 54:24-27

Kanda T, Jackson MJ, Smith LA, Pearce RK, Nakamura J, Kase H, Kuwana Y, Jenner P (1998) Adenosine A2A antagonist: a novel antiparkinsonian agent that does not provoke dyskinesia in parkinsonian monkeys. Ann Neurol 43:507-513

Kanda T, Jackson MJ, Smith LA, Pearce RK, Nakamura J, Kase H, Kuwana Y, Jenner P (2000) Combined use of the adenosine $\mathrm{A}(2 \mathrm{~A})$ antagonist $\mathrm{KW}-6002$ with L-DOPA or with selective D1 or D2 dopamine agonists increases antiparkinsonian activity but not dyskinesia in MPTPtreated monkeys. Exp Neurol 162:321-327

Kékesi KA, Kovács Z, Szilágyi N, Bobest M, Szikra T, Dobolyi Á, Juhász G, Palkovits M (2006) Concentration of nucleosides and related compounds in cerebral and cerebellar cortical areas and white matter of the human brain. Cell Mol Neurobiol 26:831-842 
Kimura T, Ho IK, Yamamoto I (2001) Uridine receptor: discovery and its involvement in sleep mechanism. Sleep 24:251-260

King AE, Ackley MA, Cass CE, Young JD, Baldwin SA (2006) Nucleoside transporters: from scavengers to novel therapeutic targets. Trends Pharmacol Sci 27:416-425

Kirmse K, Dvorzhak A, Grantyn R, Kirischuk S (2008) Developmental downregulation of excitatory GABAergic transmission in neocortical layer I via presynaptic adenosine $\mathrm{A}(1)$ receptors. Cereb Cortex 18:424-432

Kitagawa M, Houzen H, Tashiro K (2007) Effects of caffeine on the freezing of gait in Parkinson's disease. Mov Disord 22:710-712

Kittner B, Rossner M, Rother M (1997) Clinical trials in dementia with propentofylline. Ann N Y Acad Sci 826:307-316

Klein E, Zohar J, Geraci MF, Murphy DL, Uhde TW (1991) Anxiogenic effects of m-CPP in patients with panic disorder: comparison to caffeine's anxiogenic effects. Biol Psychiatry 30:973-984

Knapp CM, Foye MM, Cottam N, Ciraulo DA, Kornetsky C (2001) Adenosine agonists CGS 21680 and NECA inhibit the initiation of cocaine self-administration. Pharmacol Biochem Behav 68:797-803

Kovács Z, Dobolyi A (2011) Functions and metabolism of brain nucleosides and their metabolites. Curr Top Med Chem 11:907-908

Kovács Z, Dobolyi Á, Szikra T, Palkovits M, Juhász G (1998) Uneven regional distribution of nucleotide metabolism in human brain. Neurobiology (Bp) 6:315-321

Kovács Z, Kékesi KA, Bobest M, Török T, Szilágyi N, Szikra T, Szepesi Z, Nyilas R, Dobolyi Á, Palkovits M, Juhász G (2005) Post mortem degradation of nucleosides in the brain: comparison of human and rat brains for estimation of in vivo concentration of nucleosides. J Neurosci Methods 148:88-93

Kovács Z, Dobolyi A, Juhász G, Kékesi AK (2010a) Nucleoside map of the human central nervous system. Neurochem Res 35:452-464

Kovács Z, Juhász G, Dobolyi A, Bobest M, Papp V, Takáts L, Kékesi KA (2010b) Gender- and age-dependent changes in nucleoside levels in the cerebral cortex and white matter of the human brain. Brain Res Bull 81:579-584

Kovács Z, Juhász G, Palkovits M, Dobolyi A, Kékesi KA(2011) Area, age and gender dependence of the nucleoside system in the brain: a review of current literature. Curr Top Med Chem 11:1012-1033

Kowaluk EA, Jarvis MF (2000) Therapeutic potential of adenosine kinase inhibitors. Expert Opin Investig Drugs 9:551-564

Lajtha A, Sershen H (2010) Heterogeneity of reward mechanisms. Neurochem Res 35:851-867

Lam P, Hong CJ, Tsai SJ (2005) Association study of A2a adenosine receptor genetic polymorphism in panic disorder. Neurosci Lett 378:98-101

Lara DR, Dall'Igna OP, Ghisolfi ES, Brunstein MG (2006) Involvement of adenosine in the neurobiology of schizophrenia and its therapeutic implications. Prog Neuropsychopharmacol Biol Psychiatry 30:617-629

Latini S, Pedata F (2001) Adenosine in the central nervous system: release mechanisms and extracellular concentrations. J Neurochem 79:463-484

Ledent C, Vaugeois JM, Schiffmann SN, Pedrazzini T, El Yacoubi M, Vanderhaeghen JJ, Costentin J, Heath JK, Vassart G, Parmentier M (1997) Aggressiveness, hypoalgesia and high blood pressure in mice lacking the adenosine A2a receptor. Nature 388:674-678

Lehman NL (2002) Future potential of thymidylate synthase inhibitors in cancer therapy. Expert Opin Investig Drugs 11:1775-1787

Leist TP, Weissert R (2011) Cladribine: mode of action and implications for treatment of multiple sclerosis. Clin Neuropharmacol 34:28-35

Li RW, Tse CM, Man RY, Vanhoutte PM, Leung GP (2007) Inhibition of human equilibrative nucleoside transporters by dihydropyridine-type calcium channel antagonists. Eur J Pharmacol 568:75-82

Lima FO, Souza GR, Verri WA Jr, Parada CA, Ferreira SH, Cunha FQ, Cunha TM (2010) Direct blockade of inflammatory hypernociception by peripheral A1 adenosine receptors: involvement of the NO/cGMP/PKG/KATP signaling pathway. Pain 151:506-515 
Linden J, Rosin DL (2006) Purinergic systems. In: Siegel G, Albers RW, Brady S, Price D (eds) Basic neurochemistry: molecular, cellular and medical aspects, 7th edn. Elsevier, Academic Press Inc., New York, USA, pp 303-316

Linker RA, Kieseier BC, Gold R (2008) Identification and development of new therapeutics for multiple sclerosis. Trends Pharmacol Sci 29:558-565

Litsky ML, Hohl CM, Lucas JH, Jurkowitz MS (1999) Inosine and guanosine preserve neuronal and glial cell viability in mouse spinal cord cultures during chemical hypoxia. Brain Res 821:426-432

Liu XQ, Sheng R, Qin ZH (2009) The neuroprotective mechanism of brain ischemic preconditioning. Acta Pharmacol Sin 30:1071-1080

Lopes LV, Sebastiao AM, Ribeiro JA (2011) Adenosine and related drugs in brain diseases: present and future in clinical trials. Curr Top Med Chem 11:1087-1101

Lucas PB, Pickar D, Kelsoe J, Rapaport M, Pato C, Hommer D (1990) Effects of the acute administration of caffeine in patients with schizophrenia. Biol Psychiatry 28:35-40

Luthin DR, Linden J (1995) Comparison of $\mathrm{A}_{4}$ and $\mathrm{A}_{2 \mathrm{~A}}$ binding sites in striatum and COS cells transfected with adenosine $\mathrm{A}_{2 \mathrm{~A}}$ receptors. J Pharmacol Exp Ther 272:511-518

Mangravite LM, Badagnani I, Giacomini KM (2003) Nucleoside transporters in the disposition and targeting of nucleoside analogs in the kidney. Eur J Pharmacol 479:269-281

Markowitz CE, Spitsin S, Zimmerman V, Jacobs D, Udupa JK, Hooper DC, Koprowski H (2009) The treatment of multiple sclerosis with inosine. J Altern Complement Med 15:619-625

Marro PJ, Mishra OP, Delivoria-Papadopoulos M (2006) Effect of allopurinol on brain adenosine levels during hypoxia in newborn piglets. Brain Res 1073-1074:444-450

Martini C, Daniele S, Picchetti M, Panighini A, Carlini M, Trincavelli ML, Cesari D, Da Pozzo E, Golia F, Dell'Osso L (2011) A(2A) adenosine receptor binding parameters in platelets from patients affected by pathological gambling. Neuropsychobiology 63:154-159

McGaraughty S, Cowart M, Jarvis MF, Berman RF (2005) Anticonvulsant and antinociceptive actions of novel adenosine kinase inhibitors. Curr Top Med Chem 5:43-58

Melani A, De Micheli E, Pinna G, Alfieri A, Corte LD, Pedata F (2003) Adenosine extracellular levels in human brain gliomas: an intraoperative microdialysis study. Neurosci Lett 346:93-96

Merighi S, Mirandola P, Varani K, Gessi S, Leung E, Baraldi PG, Tabrizi MA, Borea PA (2003) A glance at adenosine receptors: novel target for antitumor therapy. Pharmacol Ther 100:31-48

Meyer PT, Elmenhorst D, Boy C, Winz O, Matusch A, Zilles K, Bauer A (2007) Effect of aging on cerebral $\mathrm{A}_{1}$ adenosine receptors: a [18 F]CPFPX PET study in humans. Neurobiol Aging 28:1914-1924

Mielke R, Moller HJ, Erkinjuntti T, Rosenkranz B, Rother M, Kittner B (1998) Propentofylline in the treatment of vascular dementia and Alzheimer-type dementia: overview of phase I and phase II clinical trials. Alzheimer Dis Assoc Disord 12(Suppl 2):S29-S35

Moreau JL, Huber G (1999) Central adenosine $A_{2 A}$ recetors: an overview. Brain Res Rev $31: 65-82$

Müller CE (2003) Medicinal chemistry of adenosine A3 receptor ligands. Curr Top Med Chem 3:445-462

Myers CS, Fisher H, Wagner GC (1994) Uridine potentiates haloperidol's disruption of conditioned avoidance responding. Brain Res 651:194-198

Nabhan C, Gartenhaus RB, Tallman MS (2004) Purine nucleoside analogues and combination therapies in B-cell chronic lymphocytic leukemia: dawn of a new era. Leuk Res 28:429-442

Nagata H, Mimori Y, Nakamura S, Kameyama M (1984) Regional and subcellular distribution in mammalian brain of the enzymes producing adenosine. J Neurochem 42:1001-1007

Noji T, Karasawa A, Kusaka H (2004) Adenosine uptake inhibitors. Eur J Pharmacol 495:1-16

Norstrand IF, Glantz MD (1980) Topographical distribution of purine nucleoside phosphorylase in the human neuraxis. Enzyme 25:118-122

Norstrand IF, Siverls VC, Libbin RM (1984) Regional distribution of adenosine deaminase in the human neuraxis. Enzyme 32:20-25

O’Regan M (2005) Adenosine and the regulation of cerebral blood flow. Neurol Res 27:175-181 
Öngür D, Drevets WC, Price JL (1998) Glial reduction in the subgenual prefrontal cortex in mood disorders. Proc Natl Acad Sci USA 95:13290-13295

Parkinson FE, Damaraju VL, Graham K, Yao SYM, Baldwin SA, Cass CE, Young JD (2011) Molecular biology of nucleoside transporters and their distributions and functions in the brain. Curr Top Med Chem 11:948-972

Pastor-Anglada M, Cano-Soldado P, Molina-Arcas M, Lostao MP, Larráyoz I, Martinez-Picado J, Casado JF (2005) Cell entry and export of nucleoside analogues. Virus Res 107:151-164

Paul T, Pfammatter JP (1997) Adenosine: an effective and safe antiarrhythmic drug in pediatrics. Pediatr Cardiol 18:118-126

Pearce L, Ghosh J, Counsell A, Serracino-Inglott F (2008) Cilostazol and peripheral arterial disease. Expert Opin Pharmacother 9:2683-2690

Pennycooke M, Chaudary N, Shuralyova I, Zhang Y, Coe IR (2001) Differential expression of human nucleoside transporters in normal and tumor tissue. Biochem Biophys Res Commun 280:951-959

Peskind ER (1996) Neurobiology of Alzheimer's disease. J Clin Psychiatry 57(Suppl 14):5-8

Peterman C, Sanoski CA (2005) Tecadenoson: a novel, selective A1 adenosine receptor agonist. Cardiol Rev 13:315-321

Pettifer KM, Kleywegt S, Bau CJ, Ramsbottom JD, Vertes E, Ciccarelli R, Caciagli F, Werstiuk ES, Rathbone MP (2004) Guanosine protects SH-SY5Y cells against beta-amyloid-induced apoptosis. Neuroreport 15:833-836

Phillips E, Newsholme EA (1979) Maximum activities, properties and distribution of 5'-nucleotidase, adenosine kinase and adenosine deaminase in rat and human brain. J Neurochem 33:553-558

Piccoli F, Camarda R, Bonavita V (1971) The brain nucleotide pattern of the rat after injection of uracil, uridine and uridine phosphate. Acta Neurol (Napoli) 26:109-117

Pinna A (2009) Novel investigational adenosine A2A receptor antagonists for Parkinson's disease. Expert Opin Investig Drugs 18:1619-1631

Podgorska M, Kocbuch K, Pawelczyk T (2005) Recent advences in studies on biochemical and structural properties of equilibrative and concentrative nucleoside transporters. Acta Biochim Pol 52:749-758

Popoli P, Blum D, Martine A, Ledent C, Ceruti S, Abbracchio MP (2007) Functions, dysfunctions and possible therapeutic relevance of adenosine A2A receptors in Huntington's disease. Prog Neurobiol 81:331-348

Porkka-Heiskanen T, Kalinchuk AV (2011) Adenosine, energy metabolism and sleep homeostasis. Sleep Med Rev 15:123-135

Radulovacki M (1985) Role of adenosine in sleep in rats. Rev Clin Basic Pharm 5:327-339

Rando RF, Nguyen-Ba N (2000) Development of novel nucleoside analogues for use against drug rersisitant strains of HIV-1. Drug Discov Today 5:465-476

Ribeiro JA, Sebastiao AM, de Mendonca A (2003) Adenosine receptors in the nervous system: pathophysiological implications. Prog Neurobiol 68:377-392

Ritchie K, Carriere I, de Mendonca A, Portet F, Dartigues JF, Rouaud O, Barberger-Gateau P, Ancelin ML (2007) The neuroprotective effects of caffeine: a prospective population study (the Three City Study). Neurology 69:536-545

Ritzel MWL, Ng AML, Yao SYM, Graham K, Loewen SK, Smith KM, Ritzel RG, Mowles DA, Carpenter P, Chen XZ, Karpinski E, Hyde RJ, Baldwin SA, Cass CE, Young JD (2001) Molecular identification and characterization of novel human and mouse concentrative $\mathrm{Na}^{+}-$ nucleoside cotransporter proteins (hCNT3 and mCNT3) broadly selective for purine and pyrimidine nucleosides (system cib). J Biol Chem 276:2914-2927

Robak T, Korycka A, Lech-Maranda E, Robak P (2009) Current status of older and new purine nucleoside analogues in the treatment of lymphoproliferative diseases. Molecules 14:1183-1226

Roberts CA (1973) Anticonvulsant effects of uridine: comparative analysis of metrazol and penicillin induced foci. Brain Res 55:291-308

Roberts CA, Kreisman NR, Waltman M (1974) Uridine anticonvulsant effects: selective control of nucleoside incorporation in experimental epilepsy. Epilepsia 15:479-500 
Roesler R, Vianna MR, Lara DR, Izquierdo I, Schmidt AP, Souza DO (2000) Guanosine impairs inhibitory avoidance performance in rats. Neuroreport 11:2537-2540

Roos RA, Bots GT, Hermans J (1985) Neuronal nuclear membrane indentation and astrocyte/ neuron ratio in Huntington's disease. A quantitative electron microscopic study. J Hirnforsch 26:689-693

Ross CA, Margolis RL, Reading SA, Pletnikov M, Coyle JT (2006) Neurobiology of schizophrenia. Neuron 52:139-153

Rudolphi KA, Schubert P, Parkinson FE, Fredholm BB (1992) Adenosine and brain ischemia. Cerebrovasc Brain Metab Rev 4:346-369

Saper CB (2006) Staying awake for dinner: hypothalamic integration of sleep, feeding, and circadian rhythms. Prog Brain Res 153:243-252

Saute JA, da Silveira LE, Soares FA, Martini LH, Souza DO, Ganzella M (2006) Amnesic effect of GMP depends on its conversion to guanosine. Neurobiol Learn Mem 85:206-212

Schiffmann SN, Fisone G, Moresco R, Cunha RA, Ferré S (2007) Adenosine A2A receptors and basal ganglia physiology. Prog Neurobiol 83:277-292

Schmidt AP, Lara DR, de Faria Maraschin J, da Silveira Perla A, Souza DO (2000) Guanosine and GMP prevent seizures induced by quinolinic acid in mice. Brain Res 864:40-43

Schmidt AP, Lara DR, Souza DO (2007) Proposal of a guanine-based purinergic system in the mammalian central nervous system. Pharmacol Therapeut 116:401-416

Schmidt AP, Böhmer AE, Schallenberger C, Antunes C, Pereira MS, Leke R, Wofchuk ST, Elisabetsky E, Souza DO (2009) Spinal mechanisms of antinociceptive action caused by guanosine in mice. Eur J Pharmacol 613:46-53

Schulte G, Fredholm BB (2003) Signalling from adenosine receptors to mitogen-activated protein kinases. Cell Signal 15:813-827

Schwarzschild MA, Agnati L, Fuxe K, Chen JF, Morelli M (2006) Targeting adenosine A2A receptors in Parkinson's disease. Trends Neurosci 29:647-654

Shen H, Chen GJ, Harvey BK, Bickford PC, Wang Y (2005) Inosine reduces ischemic brain injury in rats. Stroke 36:654-659

Sperlágh B, Vizi ES (2011) The role of extracellular adenosine in chemical neurotransmission in the hippocampus and Basal Ganglia: pharmacological and clinical aspects. Curr Top Med Chem 11:1034-1046

Spiers PA, Myers D, Hochanadel GS, Lieberman HR, Wurtman RJ (1996) Citicoline improves verbal memory in aging. Arch Neurol 53:441-448

Stone TW (2002) Purines and neuroprotection. Adv Exp Med Biol 513:249-280

Svenningsson P, Hall H, Sedvall G, Fredholm BB (1997) Distribution of adenosine receptors in the postmortem human brain: an extended autoradiographic study. Synapse 27:322-335

Teather LA, Wurtman RJ (2003) Dietary cytidine (5')-diphosphocholine supplementation protects against development of memory deficits in aging rats. Prog Neuropsychopharmacol Biol Psychiatry 27:711-717

Teather LA, Wurtman RJ (2005) Dietary CDP-choline supplementation prevents memory impairment caused by impoverished environmental conditions in rats. Learn Mem 12:39-43

Teather LA, Wurtman RJ (2006) Chronic administration of UMP ameliorates the impairment of hippocampal-dependent memory in impoverished rats. J Nutr 136:2834-2837

Togha M, Akhondzadeh S, Motamedi M, Ahmadi B, Razeghi S (2007) Allopurinol as adjunctive therapy in intractable epilepsy: a double-blind and placebo-controlled trial. Arch Med Res 38:313-316

Tomassoni D, Lanari A, Silvestrelli G, Traini E, Amenta F (2008) Nimodipine and its use in cerebrovascular disease: evidence from recent preclinical and controlled clinical studies. Clin Exp Hypertens 30:744-766

Tort AB, Mantese CE, dos Anjos GM, Dietrich MO, Dall'Igna OP, Souza DO, Lara DR (2004) Guanosine selectively inhibits locomotor stimulation induced by the NMDA antagonist dizocilpine. Behav Brain Res 154:417-422

Traut TW (1994) Physiological concentrations of purines and pyrimidines. Mol Cell Biochem 140:1-22 
Traversa U, Bombi G, Di Iorio P, Ciccarelli R, Werstiuk ES, Rathbone MP (2002) Specific [(3) H]-guanosine binding sites in rat brain membranes. Br J Pharmacol 135:969-976

Tsai SJ, Hong CJ, Hou SJ, Yen FC (2006) Association study of adenosine A2a receptor (1976 C > T) genetic polymorphism and mood disorders and age of onset. Psychiatr Genet 16:185

Tucker AL, Linden J (1993) Cloned receptors and cardiovascular responses to adenosine. Cardiovasc Res 27:62-67

Van der Beek EM, Kamphuis P (2008) The potential role of nutritional components in the management of Alzheimer's Disease. Eur J Pharmacol 585:197-207

Van Rompay AR, Johansson M, Karlsson A (2003) Substrate specificity and phosphorylation of antiviral and anticancer nucleoside analogues by human deoxyribonucleoside kinases and ribonucleoside kinases. Pharmacol Therapeut 100:119-139

Varani K, Merighi S, Gessi S, Klotz KN, Leung E, Baraldi PG, Cacciari B, Romagnoli R, Spalluto G, Borea PA (2000) [(3)H]MRE 3008 F20: a novel antagonist radioligand for the pharmacological and biochemical characterization of human $\mathrm{A}(3)$ adenosine receptors. Mol Pharmacol 57:968-975

Vinadé ER, Schmidt AP, Frizzo ME, Izquierdo I, Elisabetsky E, Souza DO (2003) Chronically administered guanosine is anticonvulsant, amnesic and anxiolytic in mice. Brain Res 977:97-102

Volonté C, D'Ambrosi N (2009) Membrane compartments and purinergic signalling: the purinome, a complex interplay among ligands, degrading enzymes, receptors and transporters. FEBS J 276:318-329

Volpini R, Costanzi S, Vittori S, Cristalli G, Klotz KN (2003) Medicinal chemistry and pharmacology of A2B adenosine receptors. Curr Top Med Chem 3:427-443

Von Lubitz DK (2001) Adenosine in the treatment of stroke: yes, maybe, or absolutely not? Expert Opin Investig Drugs 10:619-632

Wardas J (2002) Neuroprotective role of adenosine in the CNS. Pol J Pharmacol 54:313-326

Warnke C, Wiendl H, Hartung HP, Stüve O, Kieseier BC (2010) Identification of targets and new developments in the treatment of multiple sclerosis-focus on cladribine. Drug Des Devel Ther 4:117-126

Weber G, Prajda N (1994) Targeted and non-targeted actions of anti-cancer drugs. Adv Enzyme Regul 34:71-89

Weber G, Ichikawa S, Nagai M, Natsumeda Y (1990) Azidothymidine inhibition of thymidine kinase and synergistic cytotoxicity with methotrexate and 5-fluorouracil in rat hepatoma and human colon cancer cells. Cancer Commun 2:129-133

Weerts EM, Griffiths RR (2003) The adenosine receptor antagonist CGS15943 reinstates cocaineseeking behavior and maintains self-administration in baboons. Psychopharmacology (Berl) 168:155-163

Weyrich AS, Skalabrin EJ, Kraiss LW (2009) Targeting the inflammatory response in secondary stroke prevention: a role for combining aspirin and extended-release dipyridamole. Am J Ther 16:164-170

Wiesner JB, Ugarkar BG, Castellino AJ, Barankiewicz J, Dumas DP, Gruber HE, Foster AC, Erion MD (1999) Adenosine kinase inhibitors as a novel approach to anticonvulsant therapy. J Pharmacol Exp Ther 289:1669-1677

Willis RC, Carson DA, Seegmiller JE (1978) Adenosine kinase initiates the major route of ribavirin activation in a cultured human cell line. Proc Natl Acad Sci USA 75:3042-3044

Willuhn I, Wanat MJ, Clark JJ, Phillips PE (2010) Dopamine signaling in the nucleus accumbens of animals self-administering drugs of abuse. Curr Top Behav Neurosci 3:29-71

Wurtman RJ, Regan M, Ulus I, Yu L (2000) Effect of oral CDP-choline on plasma choline and uridine levels in humans. Biochem Pharmacol 60:989-992

Wurtman RJ, Cansev M, Sakamoto T, Ulus IH (2009) Use of phosphatide precursors to promote synaptogenesis. Annu Rev Nutr 29:59-87

Xu K, Bastia E, Schwarzschild M (2005) Therapautic potential of adenosine $\mathrm{A}_{2 \mathrm{~A}}$ receptor antagonists in Parkinson's disease. Pharmacol Ther 105:267-310

Yegutkin GG (2008) Nucleotide- and nucleoside converting ectoenzymes: important modulators of purinergic signalling cascade. Biochim Biophys Acta 1783:673-694 
Zapor MJ, Cozza KL, Wynn GH, Wortmann GW, Armstrong SC (2004) Antiretrovirals, part II: focus on non-protease inhibitor antiretrovirals (NRTIs, NNRTIs, and fusion inhibitors). Psychosomatics 45:524-535

Zaza A (2002) CVT-510 (CV Therapeutics). Curr Opin Investig Drugs 3:96-100

Zhao Q, Marolewski A, Rusche JR, Holmes GL (2006) Effects of uridine in models of epileptogenesis and seizures. Epilepsy Res 70:73-82

Zhao Q, Shatskikh T, Marolewski A, Rusche JR, Holmes GL (2008) Effects of uridine on kindling. Epilepsy Behav 13:47-51

Zimmermann H (1996) Biochemistry, localization and functional roles of ecto-nucleotidases in the nervous system. Prog Neurobiol 49:589-618

Zoref-Shani E, Bromberg Y, Lilling G, Gozes I, Brosh S, Sidi Y, Sperling O (1995) Developmental changes in purine nucleotide metabolism in cultured rat astroglia. Int $\mathrm{J}$ Dev Neurosci 13:887-896 